\title{
Characteristics and origin of abnormally high porosity zones in buried Paleogene clastic reservoirs in the Shengtuo area, Dongying Sag, East China
}

\author{
Cao Yingchang*, Yuan Guanghui, Li Xiaoyan, Wang Yanzhong, Xi Kelai, \\ Wang Xiaoming, Jia Zhenzhen and Yang Tian
}

School of Geosciences, China University of Petroleum, Qingdao, Shandong 266580, China

(C) China University of Petroleum (Beijing) and Springer-Verlag Berlin Heidelberg 2014

\begin{abstract}
There are three abnormally high porosity zones developed in buried Paleogene nearshore subaqueous fan and sublacustrine fan clastic reservoirs at 2,800-3,200 m, 3,250-3,700 m and 3,900$4,400 \mathrm{~m}$, respectively, within the Shengtuo area of the Dongying Sag. Here the porosity of reservoirs buried deeper than $4,000 \mathrm{~m}$ can still be greater than $20 \%$. Investigation of these three abnormally high porosity (AHP) zones in the $3^{\text {rd }}$ to $4^{\text {th }}$ member of the Paleogene Shahejie Formation in the Shengtuo area was carried out with utilization of core observation, thin section identification, SEM observation, image analysis, core physical property testing and other technical methods. The results show that, the AHP zones in 2,800-3,200 $\mathrm{m}$ and 3,250-3,700 $\mathrm{m}$ are visible pores primary AHP zones dominated by significant primary intergranular pores (more than $50 \%$ of the total porosity), while secondary pores and micropores in authigenic clays may develop in some reservoirs. AHP reservoirs in the AHP zone of 3,900-4,400 m are dominated by micropores in matrix, visible pores are mainly grain dissolution pores but with low absolute content $(<1 \%)$, so this zone belongs to the micropores primary AHP zone. The genesis of the three AHP zones was studied to distinguish between porosity enhancement and porosity preservation. Our research shows that, in deeply buried clastic reservoirs in the Shengtuo area, mineral dissolution occurred in a relatively closed diagenetic system with high temperature and high salinity. Reservoir rocks underwent extensive feldspar dissolution, while detrital carbonate grains and carbonate cements show no evidence of extensive dissolution. Although significant feldspar dissolution pores developed, feldspar dissolution enhanced porosity only a little due to the precipitation of almost isovolumetric dissolution products in the nearby primary intergranular pores in forms of authigenic clays and quartz cements. Net enhanced porosity originating from feldspar dissolution is generally less than $0.25 \%$. Thus, the subsurface dissolution has little impact on the mid-deep buried high porosity reservoirs. Reservoirs in braided channels of middle fans in sublacustrine fans and reservoirs in the middle-front of fan bodies of nearshore subaqueous fans provide the basis for the development of AHP zones. The shallow development of fluid overpressure and early hydrocarbon emplacement have effectively retarded compaction and carbonate cementation, so that the high porosity in the superficial layers is preserved in the mid-deep layers. These are the main controlling factors in the development of AHP zones.
\end{abstract}

Key words: Dongying Sag, Shengtuo area, abnormally high porosity zone, pores, genesis

\section{Introduction}

Studies by Bloch et al (2002) of global basins show that in specific geological conditions, deeply buried reservoirs can still be effective for accumulation and production of petroleum and in particular that some areas exhibit

*Corresponding author. email: caoych@upc.edu.cn

Received May 11, 2013 unexpectedly high porosity and permeability at substantial burial depth. Studies on the origin and distribution of these high-quality abnormally high porosity (AHP) reservoirs are of great importance for oil-gas exploration and production. Bloch et al (2002) defined AHP as reservoir porosity which is statistically higher than the porosity values occurring in typical sandstone reservoirs of a given lithology (composition and texture), age and burial/temperature history. In sandstones containing abnormally high porosities, such porosities 
exceed the maximum porosity of the typical sandstone subpopulation. With inspiration from this definition, Meng et al (2010) defined the AHP zone as the reservoir development zone with porosities higher than the maximum porosity of clastic rocks that develop in normal sedimentary and diagenetic environments. The concept of an AHP zone emphasizes only the abnormally high level of reservoir porosity regardless of the pore types. In addition, Chinese scholars also referred to the AHP zone as the secondary pore development zone, secondary pore zone, (abnormal) pore development zone, secondary pore development section, etc., of which, the secondary pore development zone has been used widely (Yuan and Wang, 2001; Zhu et al, 2006; Liu et al, 2009; Wang, 2010). Some scholars considered the relative content of secondary pores in the reservoirs (Wang and Shao, 1999; Wang, 2010), for example, Wang (2010) summarized studies of the Chinese scholars, and defined the secondary pore development zone as a zone where reservoirs with high porosity (higher than the $\Phi_{\text {cutoff }}$ ) developed, based on the introduction of effective reservoir porosity cutoff $\left(\Phi_{\text {cutoff }}\right)$, and where the percentage of secondary pores in reservoirs is more than $50 \%$. However, without considering the content of secondary pores in reservoirs, some scholars subjectively defined the concentrated development zone of AHP reservoirs with secondary pores as the secondary pore development zone (Zhong et al, 2003; Xiao et al, 2003; Liu and Zhu, 2006; Zhu et al, 2007; Zhang et al, 2011).

Publications suggest that both geological processes beneficial to porosity preservation (e.g. (1) the shallow development of fluid overpressure and chlorite coats, and (2) early hydrocarbon emplacement) and processes beneficial to porosity enhancement (mineral dissolution) can be the important controlling factors to the development of middeep AHP reservoirs (Ehrenberg, 1993; Warren and Pulham, 2001; Luo et al, 2002; Bloch et al, 2002; Marchand et al, 2002; Zhong et al, 2003; Zhu et al, 2004; 2006; Zhang et al, 2007; Yu et al, 2008; Peng et al, 2009; Zhong et al, 2008; Taylor et al, 2010; Meng et al, 2010; Wang, 2010; Jin et al, 2011; Chen et al, 2011; Zhu et al, 2012). Even recently, most Chinese scholars still thought that burial dissolution of minerals (particularly mesogenenic dissolution) is the main controlling factor of the mid-deep AHP zones (Zhang et al, 2003; Zhu et al, 2004; Yuan et al, 2007; Zhu et al, 2006; Yu et al, 2008; Zhong et al, 2008; Zhu et al, 2012). In recent years, many foreign scholars and some Chinese scholars began to accentuate the importance of geological processes beneficial to porosity preservation (e.g. fluid overpressure, hydrocarbon emplacement and chlorite coats), and rethought the importance of secondary pores (Bloch et al, 2002; Taylor et al, 2010; Berger et al, 2009; Marchand et al, 2002; Higgs et al, 2007; Jin et al, 2011; Ehrenberg et al, 2012; Yuan et al, 2013b). When geological processes beneficial to porosity preservation serve as main controlling factors, AHP reservoirs consist mainly of primary pores; while when the secondary dissolution is the main controlling factor, the AHP reservoirs consist mainly of secondary pores (Bloch et al, 2002; Meng et al, 2006; 2010). Thus, we suggested dividing the AHP zones into two types: the primary AHP zone (the relative percentage content of primary pores in reservoirs is more than 50\%) and the secondary AHP zone (the relative percentage content of secondary pores in reservoirs is more than $50 \%$ ) (Cao et al, 2013). Also, exploration ideas and methods should differ between these types of AHP zones.

The mid-deep clastic reservoirs $(>2,500 \mathrm{~m})$ in the Shengtuo area of the northern steep slope zone in the Dongying Sag developed three AHP zones at 2,800-3,200 $\mathrm{m}, 3,250-3,700 \mathrm{~m}$ and 3,700-4,400 m, respectively. Great success has been achieved in oil-gas exploration in $\mathrm{Es}_{4}-\mathrm{Es}_{3}{ }^{\mathrm{Z}}$ subtle reservoirs in recent years. For example, Well T71, Well T76, Well T710, Well T719 and Well T764 all obtained high yields in the $\mathrm{Es}_{4}-\mathrm{Es}_{3}{ }^{\mathrm{x}}$ formations. However, there is still much debate on pore types and genesis of the AHP reservoirs. Previous studies suggested that, the deep buried Paleogene clastic reservoirs in the Shengtuo area consist mainly of secondary pores, and subsurface dissolution is the main controlling factor of these AHP zones (Zhong et al, 2003; Zhu et al, 2006; Yuan et al, 2007; Gao et al, 2008). Among them, Zhong et al (2003) and Zhu et al (2006) proposed that the reservoirs consist mainly of intergranular dissolution pores, and significant dissolution of carbonate cements is critical to the AHP zones. However, Yuan et al (2007) and Gao et al (2008) argued that the dissolution of carbonate cements is not obvious, and significant feldspar pores contribute more to these AHP zones. Geological factors beneficial to primary pore preservation, such as fluid overpressure and hydrocarbon emplacement occur commonly in the Shengtuo area (Zhang et al, 2009; Wang, 2010; Sun, 2010). However, the AHP zones were identified as secondary AHP zones (secondary pore development zones) by previous studies (Zhong et al, 2003; Zhu et al, 2006; Yuan et al, 2007; Gao et al, 2008), which is questionable. Using core observation, thin section identification, SEM analysis, image analysis, rock physical property tests, fluid inclusion analysis, statistical analysis and other techniques, on the basis of the distribution of AHP zones in the Shengtuo area, we studied the pore types and the genesis of these AHP zones.

\section{Geological background}

The Dongying Sag is a sub-tectonic unit lying in the southeastern part of the Jiyang Depression of the Bohai Bay Basin, East China (Fig. 1(a)). It is a Mesozoic-Cenozoic half graben rift-downwarped lacustrine basin, developed on Paleozoic bedrock paleotopography (Yuan et al, 2007). The Dongying Sag, which is located west of the Qingtuozi Salient, north of the Luxi Uplift and Guangrao Salient, east of the Linfanjia and Gaoqing Salient, south of the ChenjiazhuangBinxian Salient. It covers an area of $5,850 \mathrm{~km}^{2}$ with an eastwest axis of $90 \mathrm{~km}$ and a north-south axis of $65 \mathrm{~km}$. In profile, the Dongying Sag is a half graben with a faulted northern margin and a gentle southern margin. In plan, the Dongying sag is further subdivided into secondary structural units, such as the northern steep slope zone, middle uplift belt, trough zones of the Lijin, Minfeng, Niuzhuang and Boxing subsags, and the southern gentle slope zone (Zhang et al, 2006) (Fig. $1(b))$.

The Shengtuo area is located in the middle part of the northern steep slope zone of the Dongying sag, with the 


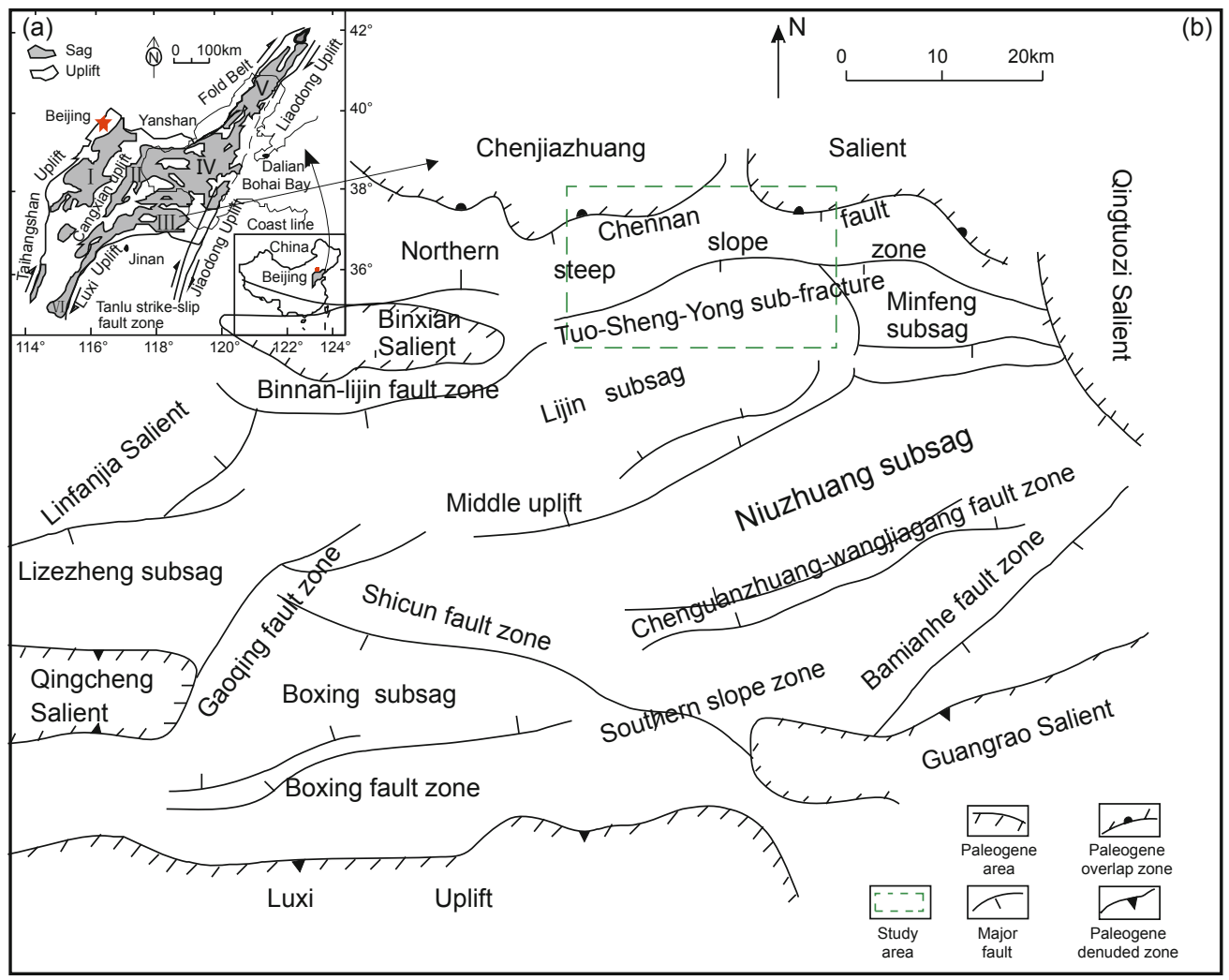

Fig. 1 (a) Tectonic setting of the Dongying Sag in the Jiyang Depression ( III ) of the Bohai Bay Basin, East China. Other depressions in the Bohai Bay Basin are Jizhong Depression ( I), Huanghua Depression (II), Bozhong Depression (IV), Liaohe Depression (V) and Dongpu Depression (VI) (After Liu et al, 2012). (b) Structural map of the Dongying Sag. The area in the green line is the study area (After Zhang et al, 2006).

Chenjiazhuang Salient to the north, the central faulted anticlinal zone to the south, the Lijin subsag to the southwest and the Minfeng subsag to the southeast, with an exploration area of $230 \mathrm{~km}^{2}$ (Gao et al, 2008) (Fig. 1(b)). The basin controlling boundary Chennan fault and the secondary TuoSheng-Yong sub fracture system, jointly controlled the terrace tectonic style in the Shengtuo area, and had important influence on sediments and reservoirs (Fig. 2). During the early period of $\mathrm{Es}_{4}{ }^{\mathrm{x}}$, the Tuo-Sheng-Yong sub fracture system had not yet begun to develop, and nearshore subaqueous fans deposited. From the late period of $\mathrm{Es}_{4}{ }^{\mathrm{x}}$ to the period of $\mathrm{Es}_{3}{ }^{\mathrm{z}}$, the Tuo-Sheng-Yong sub fracture system developed and formed the terrace. The nearshore subaqueous fans deposited on the terrace that was constrained by the Chennan fault and Tuo-Sheng-Yong sub fracture system, and sublacustrine fans deposited in the subsag that was close to the Tuo-ShengYong sub fracture system (An, 2010) (Fig. 2). Controlled by the tectonic setting, the formation fluid pressure in the Shengtuo area has apparent zoning. Normal and weak fluid overpressure developed mainly in the nearshore subaqueous fans, and medium-strong overpressure with the pressure coefficient of 1.2-1.8 developed in the sublacustrine fans (Gao et al, 2008; An, 2010).

\section{Petrography and diagenesis}

\subsection{Petrography}

The data show that in the mid-deep Paleogene reservoirs in the Shengtuo area, the quartz content is $5 \%-63 \%$ with an average of $32 \%$, the feldspar content is $4 \%-74 \%$ with an average of $37 \%$ and the detritus content is $3 \%-88 \%$ with an average of $30 \%$. The reservoir rocks consist mainly of lithic arkose and feldspathic lithic sandstones (Fig. 3). On the whole, detrital grains are moderately to poorly sorted, with sub-angular or sub-rounded shapes. Grain contacts are mainly point contact and point-line contact.

\subsection{Diagenesis features}

According to the new diagenetic stage division standard of clastic reservoirs in China's oil and gas industry (Standard No. SY/T5477-2003), the Paleogene $\mathrm{Es}_{4}-\mathrm{Es}_{3}{ }^{\mathrm{Z}}$ reservoirs at depths of 1,500-4,500 $\mathrm{m}$ in the Shengtuo area are mainly in the eogenetic and mesogenetic stages. Among them, 1,5002,200 m belongs to the eogenetic stage A period, 2,200-3,000 $\mathrm{m}$ belongs to the $\mathrm{B}$ period of the eogenetic stage, 3,000-3,500 $\mathrm{m}$ belongs to the A1 sub-period of the mesogenetic stage, and 3,500-4,500 m belongs to the mesogenetic stage A2 subperiod (Table 1). The major diagenetic events in the reservoir rocks include compaction, carbonate cements (mainly calcite, dolomite, ferroan calcite and ankerite), quartz cements, feldspar dissolution, quartz dissolution, authigenetic clays (kaolinite and illite) and illitization of kaolinite (Fig. 4, Fig. 5). Using textural evidence of precipitation and dissolution of minerals and the homogenization temperatures $\left(T_{\mathrm{h}}\right)$ of fluid inclusions, the epigenetic sequence was determined as follows: 1) compaction, early carbonate cementation 


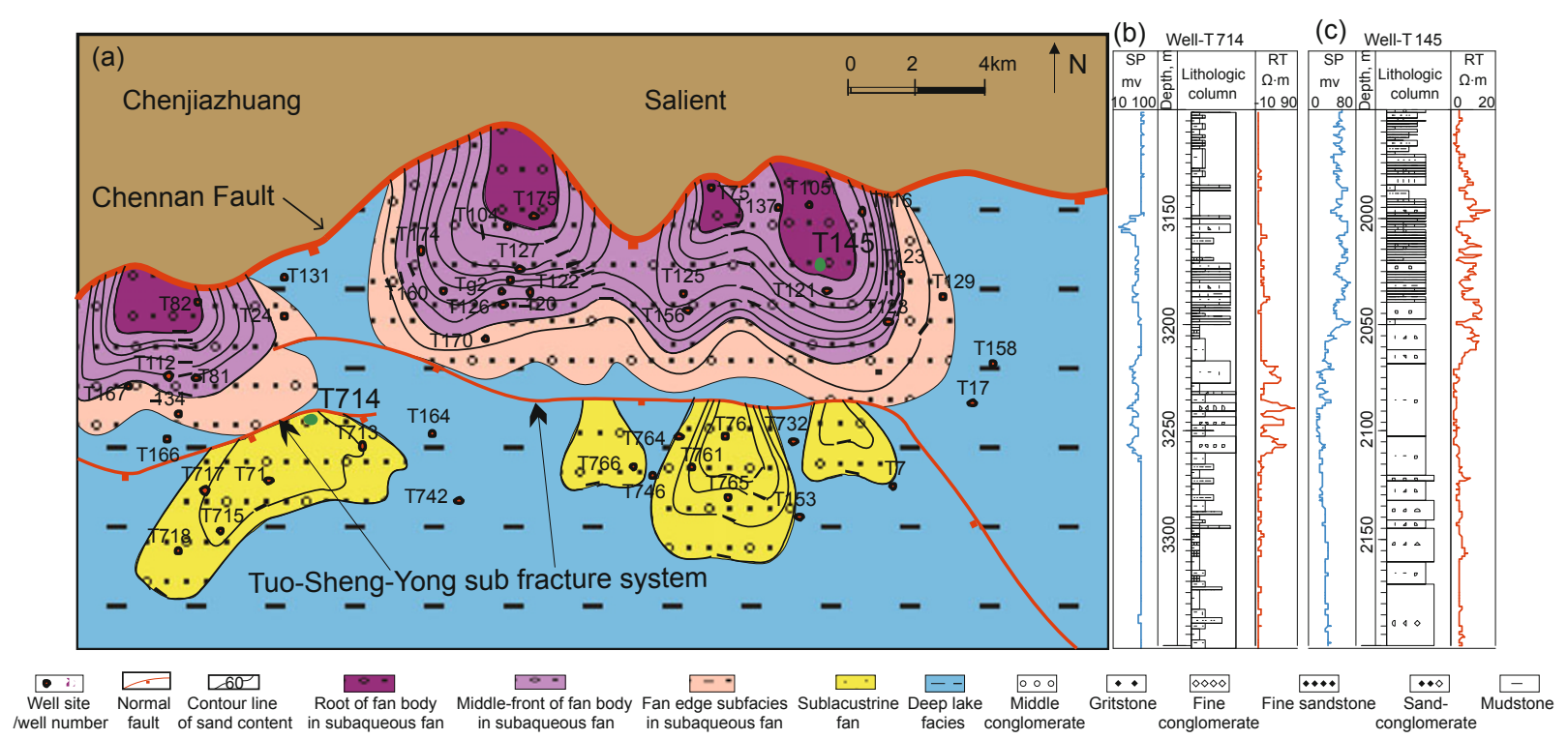

Fig. 2 (a) Distribution map of nearshore subaqueous fans and sublacustrine fans in $\mathrm{Es}_{4}{ }^{\mathrm{s}}$ in the Shengtuo area (modified from An, 2010). (b) Depositional sequence of sublacustrine fans and deep lake facies. (c) Depositional sequence of nearshore subaqueous fans

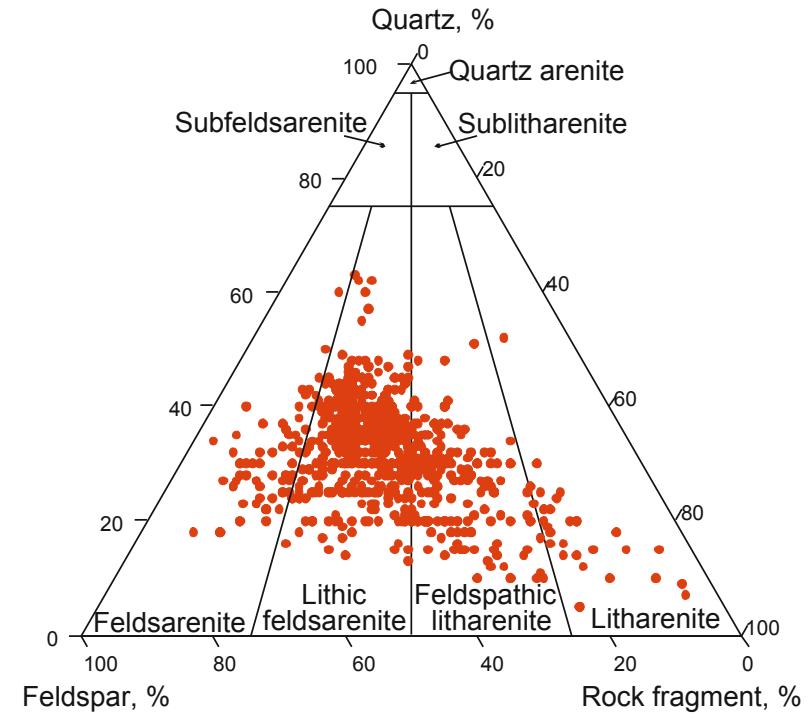

Fig. 3 Ternary plot showing composition of Paleogene $\mathrm{Es}_{4}-\mathrm{Es}_{3}{ }^{\mathrm{z}}$ reservoirs in the Shengtuo area, the Dongying Sag (using sandstone classification scheme of Folk et al, 1970)

(Fig. 5(c)-(d)); 2) feldspar dissolution, quartz cementation, authigenic kaolinite precipitation (Fig. 4(c)); 3) quartz dissolution, late carbonate cementation (Fig. 4(g)); 4) feldspar dissolution, quartz cementation (Fig. 5(g)), illitization of kaolinite and authigenic illite precipitation (Fig. 4(e)-(f)).

The compaction was mainly mechanical compaction, and pressure dissolution was weak. The dissolution mainly includes feldspar dissolution (Fig. 4(c), (e), (g); Fig. 5(c), (e)), a little dissolution of aluminosilicate detrital grains and quartz grains. Detrital carbonate grains (Fig. 5(b), (e)(f)) and carbonate cements (Fig. 5(c)-(h)) show no evidence of significant dissolution. Carbonate cements represent the most abundant pore-filling cements (Fig. 5), with a maximum content up to $35 \%-40 \%$ (Fig. 6) and an average content of
$9 \%$. The quartz cements, generally less than $1 \%$ in reservoirs, are mainly quartz overgrowths (Fig. 4(c), (f), (h)) and a few quartz crystals. The distribution of authigenic clay minerals in reservoirs has a regularity: above $3,150 \mathrm{~m}$ is mainly kaolinite, and sharply below 3,150 m kaolinite transforms to illite (Fig. $6)$. From the shallow to the deep layers, the relative content of illite/smectite mixed layer minerals increases, but the ratio of smectite in illite/smectite mix minerals decreases gradually (Fig. 6). Scaly or petal shaped chlorite, but no early grain coating chlorite, develops in some reservoir rocks (Zhu et al, 2008; Chen et al, 2009).

\section{Distribution of porosity intervals and zones}

\subsection{Porosity interval and zone classification scheme}

Core porosities of Paleogene $\mathrm{Es}_{4}-\mathrm{Es}_{3}{ }^{\mathrm{z}}$ reservoirs were used to plot the porosity-depth profile. In the porosity-depth profile, normal porosity development depth intervals, AHP development depth intervals, and AHP zones, high porosity zones, low porosity zones in different depth intervals were identified with the constraints of three curves, namely, the normal evolution curve of average porosity, the normal evolution curve of maximum porosity and the porosity envelope curve. In the porosity-depth profile, the zones where reservoirs with porosities that deviated from the normal evolution curve of maximum porosity to higher values is recognized as AHP zones; the zones where reservoirs with porosities that deviated from the normal evolution curve of maximum porosity to lower values but deviated from normal evolution curve of average porosity to higher values is recognized as high porosity zones; the zones where reservoirs with porosities that deviated from normal evolution curve of average porosity to lower values is recognized as low porosity zones. In the porosity-depth profile, the depth interval 
Table 1 Diagenetic stages and main characteristics of the $\mathrm{Es}_{4}-\mathrm{Es}_{3}{ }^{\mathrm{z}}$ reservoirs in the Shengtuo area, the Dongying Sag

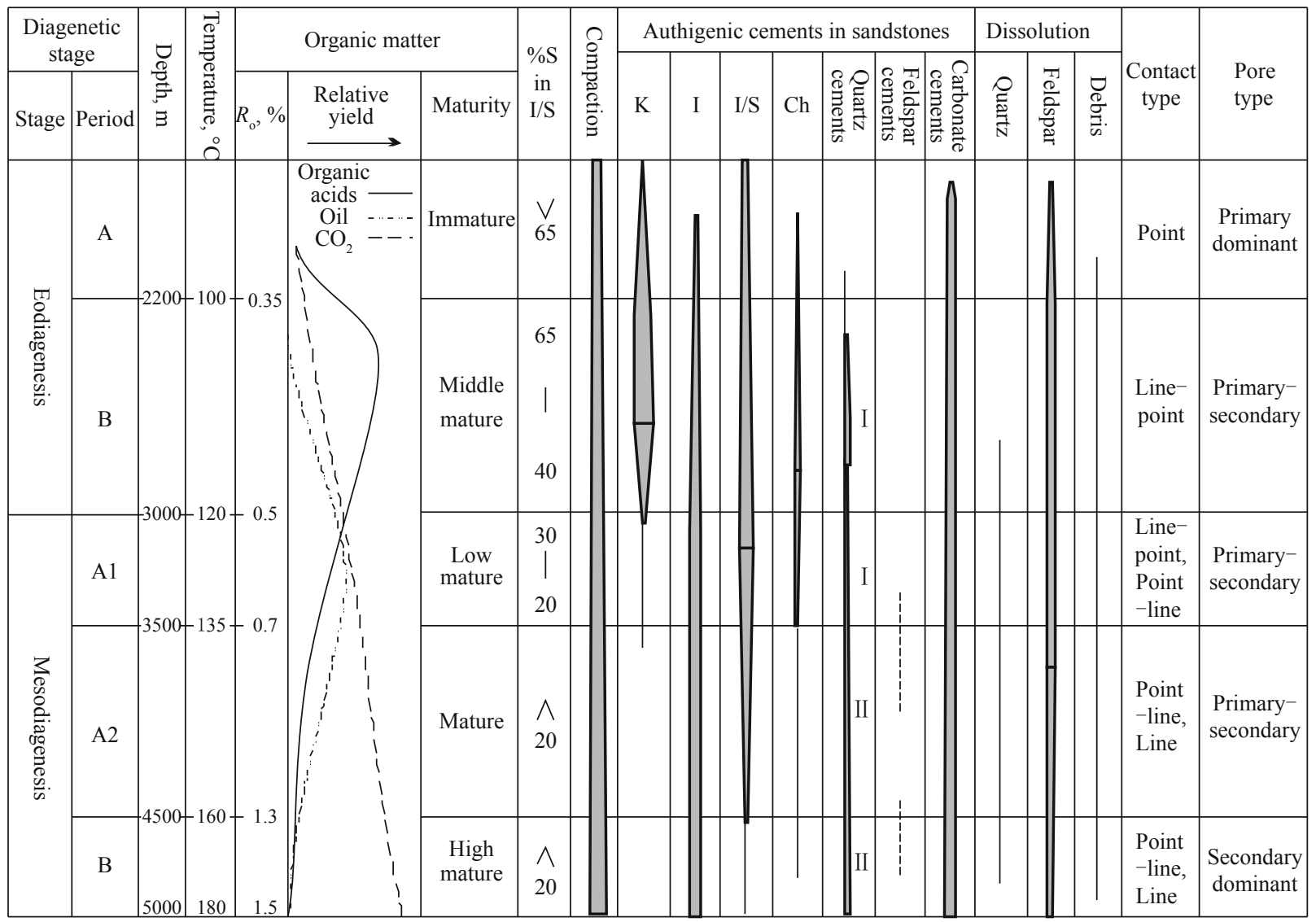

with AHP zones is recognized as the AHP development depth interval and the depth interval without AHP zones is recognized as the normal porosity development depth interval.

\subsection{Normal evolution curve of maximum (average) porosity}

The normal evolution curve of maximum porosity in clastic reservoirs refers to the evolution curve of the maximum porosity evolving with the burial depth in reservoirs that did not experience abnormal geological processes in favor of porosity enhancement and porosity preservation during deep burial. It can be determined by connecting the maximum porosity at different depths with a smooth curve in the porosity-depth profile. Among these abnormal geological processes, the process in favor of porosity enhancement is the dissolution of unstable minerals (e.g. feldspars and carbonate minerals), while the processes in favor of porosity preservation consist mainly of fluid overpressure, early hydrocarbon emplacement, and grain coats. Thus, the normal evolution curve of maximum porosity almost follows the compaction curve.

In order to determine the distribution of AHP zones in the Shengtuo area, we did the following work. First, with the constraints of the measured formation fluid pressure, the formation fluid pressure of over 300 wells in the northern steep slope zone in the Dongying Sag was calculated by the equivalent-depth method with acoustic logging data.
Comparison between calculated mudstone fluid pressure and measured adjacent sandstone fluid pressure shows that the difference is always less than $5 \%$. As well, the oilbearing properties of more than 8,000 reservoir samples with core porosity data were analyzed with core-logging materials. Second, by rejecting the porosities relating to fluid overpressure and/or high-level oil saturation (oil immersion, oil saturated and oil rich) from the porosity database, one porosity-depth profile was plotted using reservoir porosities with normal pressure and low level oil content (oil-free, oil trace, fluorescence and oil patches). The normal evolution curve of maximum porosity in $\mathrm{Es}_{4}-\mathrm{Es}_{3}{ }^{\mathrm{z}}$ reservoirs in the northern steep slope zone in the Dongying Sag was then determined through the smooth connection of maximum porosities at different depths in such a porosity-depth profile (Fig. 6). As early grain-coating chlorite was not developed, and reservoirs with significant dissolution also have relatively good oiliness, the rejection of porosities relating to fluid overpressure and/or high-level oil saturation from porosity database promises the elimination of the influence of abnormal geological processes (fluid overpressure, hydrocarbon emplacement, grain coats and rims, and dissolution) on porosities in the Shengtuo area.

The normal evolution curve of average porosity in clastic reservoirs refers to the evolution curve of the average porosity evolving with the burial depth in reservoirs that did not experience abnormal geological processes in favor of porosity enhancement and porosity preservation during deep burial. On 

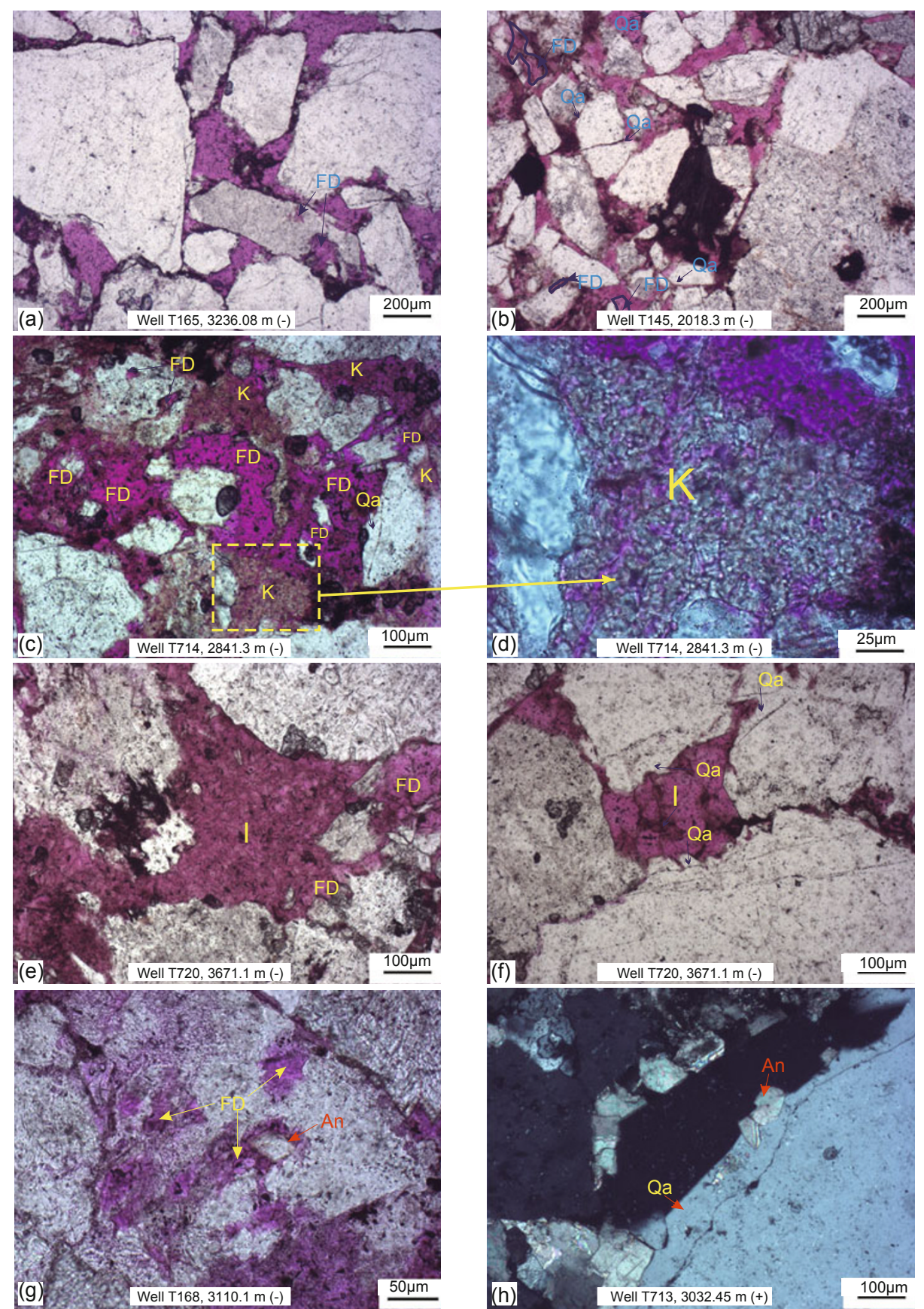

Fig. 4 Photomicrographs showing diagenetic features related to feldspar dissolution in Paleogene $\mathrm{Es}_{4}-\mathrm{Es}_{3}{ }^{ }{ }^{\mathrm{r}}$ reservoirs in the Shengtuo area, the Dongying Sag. (a) Primary pores dominate, surface porosity of feldspar dissolution is $0.1 \%$; (b) Primary pores dominate, surface porosity of feldspar dissolution is $0.5 \%$; (c) Massive quartz overgrowths and kaolinite, surface porosity of feldspar dissolution is $2.462 \%$; (d) Authigenic kaolinite and its micropores; (e) feldspar secondary pores and authigenic illite; (f) Quartz overgrowths and authigenic illite; (g) Feldspar pores partially filled with ankerite; (h) Quartz overgrowths partially replaced by ankerite, thin section. (a-g) red epoxy resin-impregnated thin section. FD: Feldspar dissolution pores; Qa: Quartz overgrowths; K: Kaolinite; I: Illite; An: Ankerite

the basis of the normal evolution curve of maximum porosity in clastic reservoirs, the normal average porosity of different depth intervals can be calculated using reservoir porosities with normal pressure and low oil-bearing saturation. Then in the porosity-depth profile, the normal evolution curve of average porosity in clastic reservoirs can be determined by connecting the average porosities at different depths with a smooth curve (Fig. 6).

\subsection{Porosity intervals and zones}

With the constraints of the three curves, 3,880 core porosities in the Shengtuo area show one normal porosity development depth interval at depth of 1,300-2,800 m and three AHP development depth intervals developed vertically in $\mathrm{Es}_{4}-\mathrm{Es}_{3}{ }_{3}$ reservoirs in the Shengtuo area. The three AHP development depth intervals are at 2,800-3,200 m, 3,250$3,700 \mathrm{~m}, 3,900-4,400 \mathrm{~m}$ respectively, and three AHP zones 

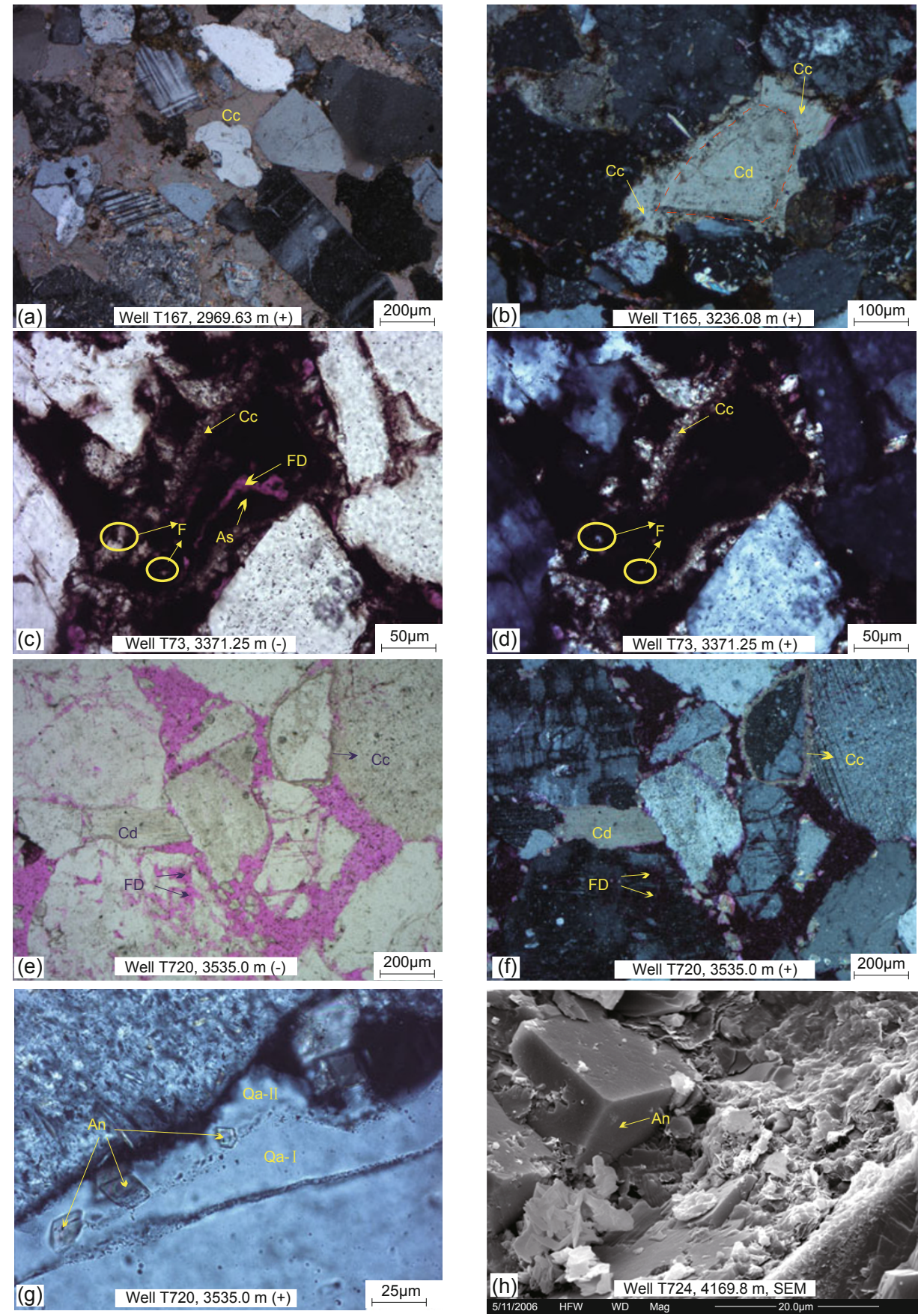

Fig. 5 Photomicrographs showing diagenetic features related to carbonate cements in Paleogene $\mathrm{Es}_{4}-\mathrm{Es}_{3}{ }^{2}$ reservoirs in the Shengtuo area, the Dongying Sag. (a) Carbonate cement filled most pores, (b) Carbonate detrital grain and the carbonate overgrowths, (c), (d) Intact early carbonate cement cladding and extensive dissolved feldspar, feldspar dissolution pores partially filled with asphalt, (e), (f) Intact carbonate detrital grains and early carbonate cement cladding, extensively dissolved feldspars, (g) Two stages of quartz overgrowths, intact ankerite wrapped in Qa-II, (h) Euhedral ankerite cements. (a, b, g): thin sections; (c-f) red epoxy resinimpregnated thin section; Cc: Carbonate cements; Cd: Detrital carbonate grain; FD: Feldspar dissolution pores; As: Asphalt; An: Ankerite; Qa: Quartz overgrowths

exist in the three AHP development depth intervals (Fig. 6). Low porosity zones and high porosity zones develop in the normal porosity development depth interval, while the three AHP development depth intervals contain the corresponding low porosity zones, high porosity zones and AHP zones.

In the AHP development interval I (2,800-3,200 m), porosities have a bimodal distribution pattern, and are mainly distributed in $2 \%-24 \%$ (Fig. 7). In the porosity data set, the low porosities account for $35 \%$, the high porosities $33 \%$, and the abnormally high porosities $32 \%$. In the AHP development interval II $(3,250-3,700 \mathrm{~m})$, the histogram of porosities shows negative skewness, and the porosities are mainly distributed in $2 \%-20 \%$ (Fig. 7). In the porosity data set, the low porosities account for $46 \%$, the high porosities $37 \%$, and 

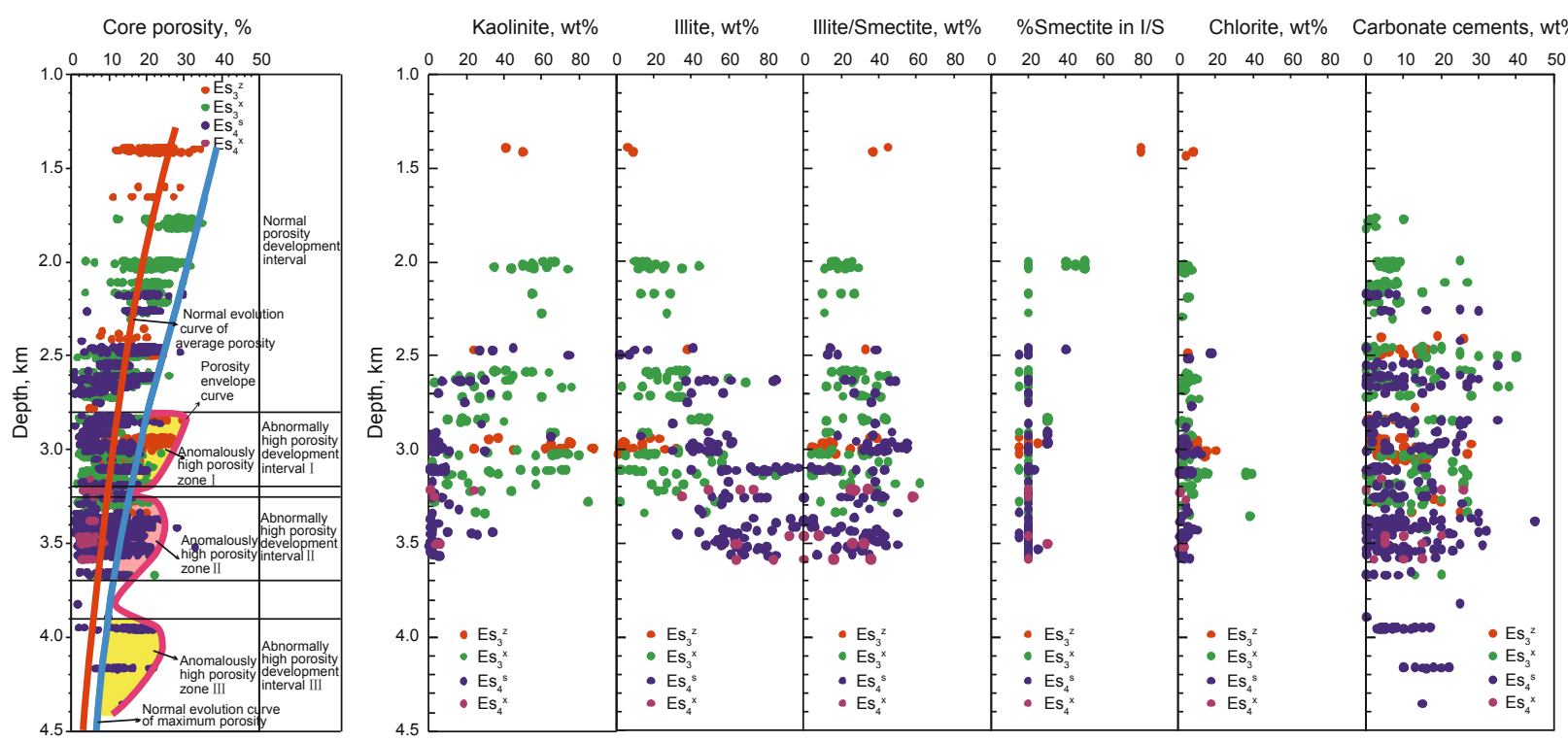

Fig. 6 Vertical distribution of core porosities, clays and carbonate cements in Paleogene $\mathrm{Es}_{4}-\mathrm{Es}_{3}{ }^{\mathrm{z}}$ reservoirs in the Shengtuo area, the Dongying Sag

the abnormally high porosities $23 \%$. In the AHP development interval III $(3,900-4,400 \mathrm{~m})$, the histogram of porosities distribution shows positive skewness, and the porosities are mainly distributed in 6\%-22\% (Fig. 7). The low porosities account for $1 \%$, the high porosities $9 \%$, and the abnormally high porosities $90 \%$.
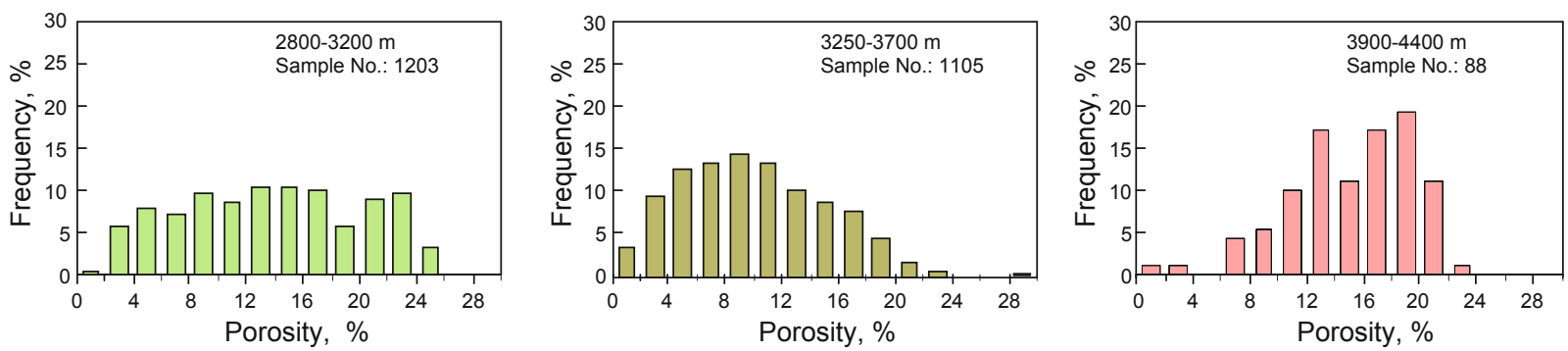

Fig. 7 Histograms of porosities in different AHP development depth intervals in the Shengtuo area, the Dongying Sag

\section{Reservoir pores}

In order to determine the type of an AHP zone, the relative content and absolute content of primary pores and secondary pores in reservoirs should be considered together. From Fig. 8, it can be seen that, with an increase of core porosity, both the primary thin section porosity and the secondary thin section porosity tend to increase, but the percentage of primary thin section porosity increases and the percentage of secondary thin section porosity decreases generally. For AHP zone I $(2,800-3200 \mathrm{~m})$ and II (3,250-3,700 m), reservoirs with AHP consist mainly of visible pores (Fig. 9(a), (b); Fig. 10(a), (b)), and the content of micropores is much less than that of visible pores. In reservoirs with AHP, primary pores dominate the visible pores and account for $50 \%-90 \%$ of the total visible pores (Fig. 8), so AHP zones I and II should be primary AHP zones. The secondary surface porosity in reservoirs with AHP ranges from $0.5 \%$ to $3.0 \%$. Micropores in authigenic clays also develop when significant dissolution pores develop.
For AHP zone III $(3,900-4,400 \mathrm{~m})$, the percentage of secondary surface porosity in the total surface porosity is about $100 \%$, but its absolute value is always less than $1 \%$. Core porosities can reach up to $15 \%-22 \%$ (Fig. 8), and polished thin section and SEM samples show that micropores in the matrix (Fig. 9(g), (h); Fig. 10(c)) develop and contribute much more to the core porosity than secondary pores. As a result, this zone should also be identified as the primary AHP zone, but with predominantly micropores in the matrix.

The pores in high porosity sandstones in different AHP development depth intervals are complex, and the reservoir space consists of not only primary pores (Fig. 8; Fig. 9(b), (e)), but sometimes secondary pores. However, for the low porosity reservoirs, due to strong compaction or extensive carbonate cementation, the reservoir space consists just a small proportion of secondary pores or matrix micropores (Fig. 8; Fig. 9(c), (f), (i)), and visible pores do not develop. 


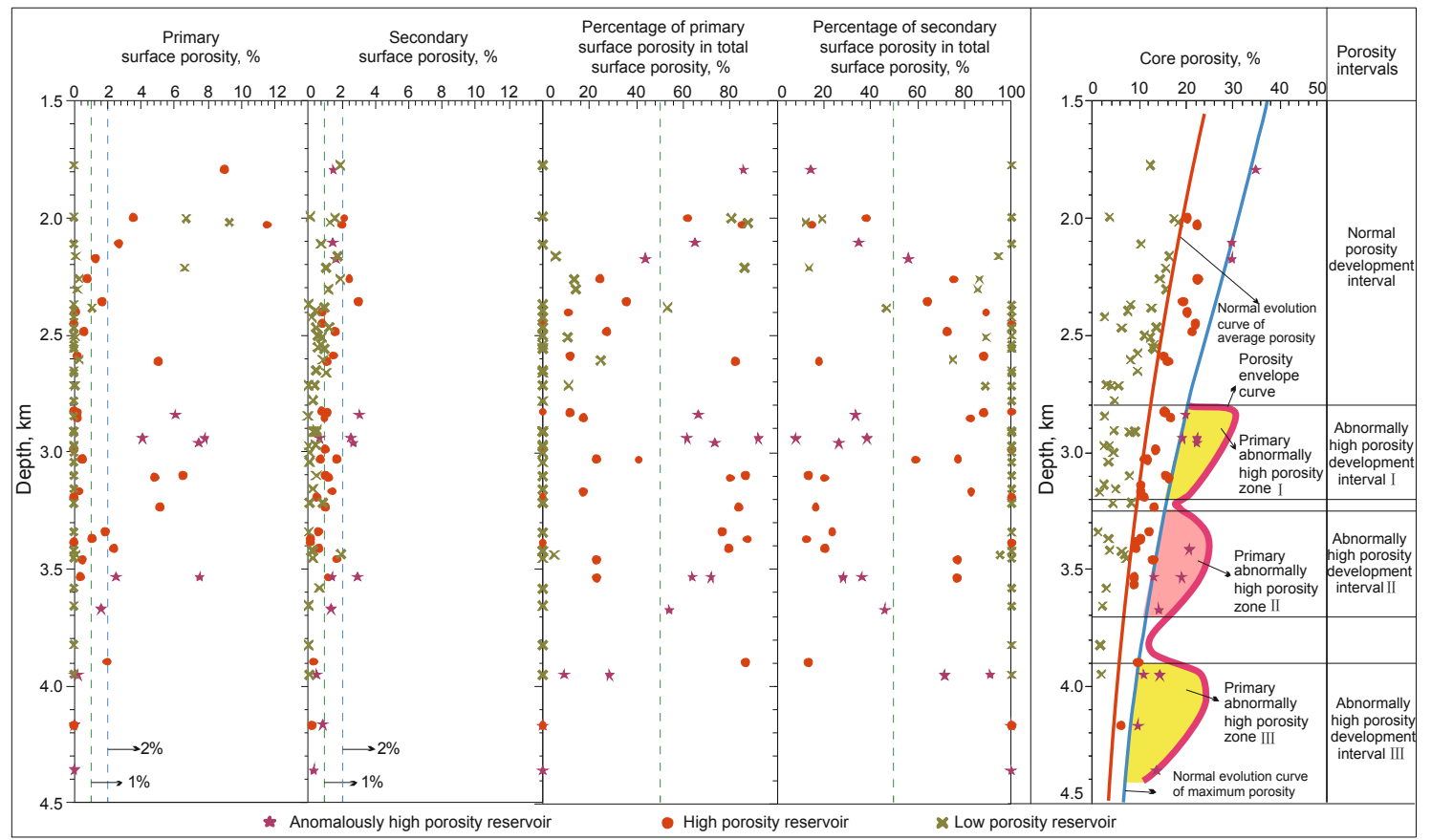

Fig. 8 Core plug porosity, secondary surface porosity, percentage of secondary surface porosity in total surface porosity and percentage of primary surface porosity in total surface porosity in Paleogene $\mathrm{Es}_{4}-\mathrm{Es}_{3}{ }^{2}$ reservoirs in the Shengtuo area, Dongying Sag. For each core porosity sample, there are matched thin section and red epoxy resin-impregnated thin section

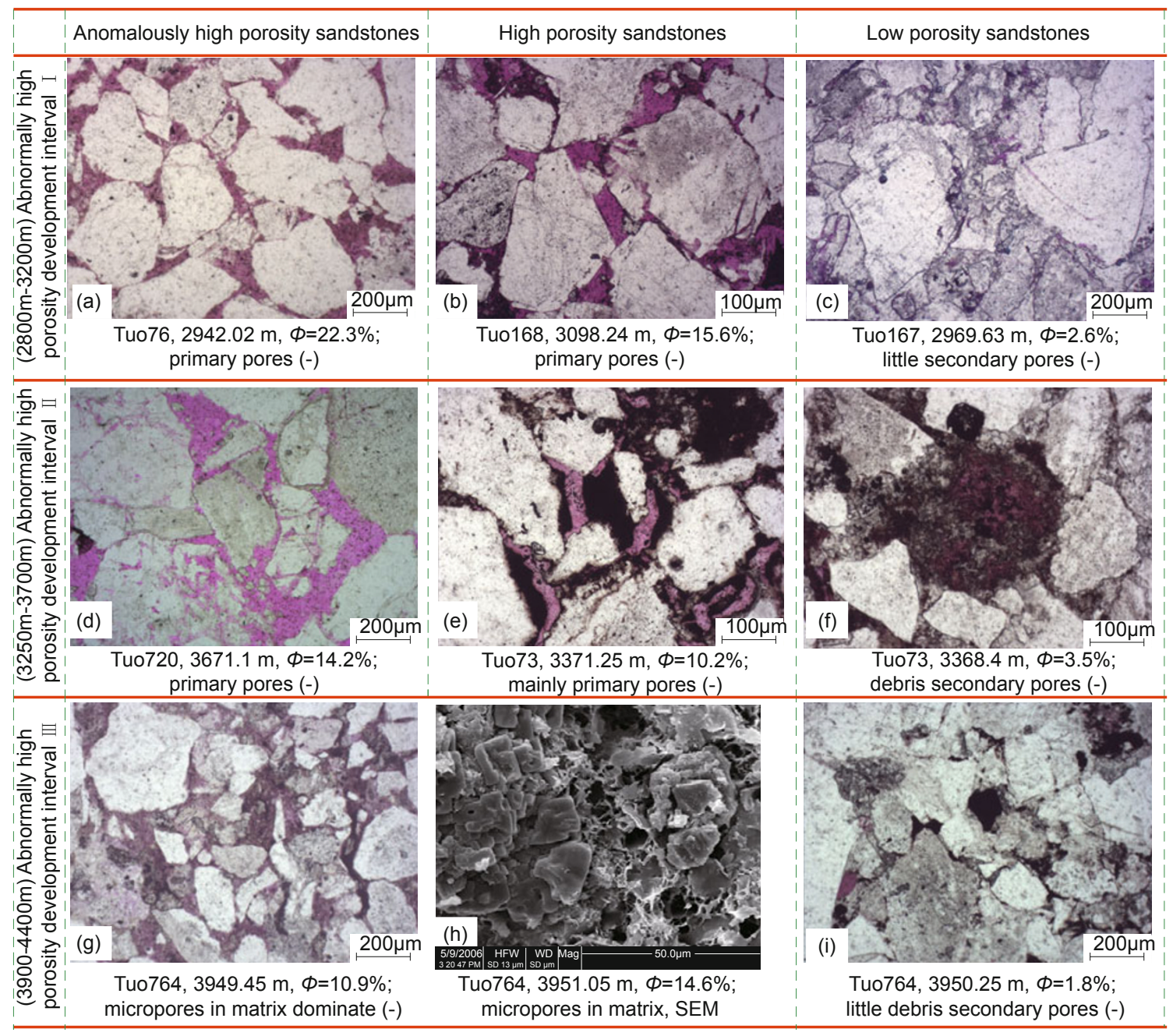

Fig. 9 Photomicrographs showing pores of Paleogene $\mathrm{Es}_{4}-\mathrm{Es}_{3}{ }^{\mathrm{z}}$ reservoirs with different porosity levels in different AHP development intervals. (a-g, i): red epoxy resin-impregnated thin section 


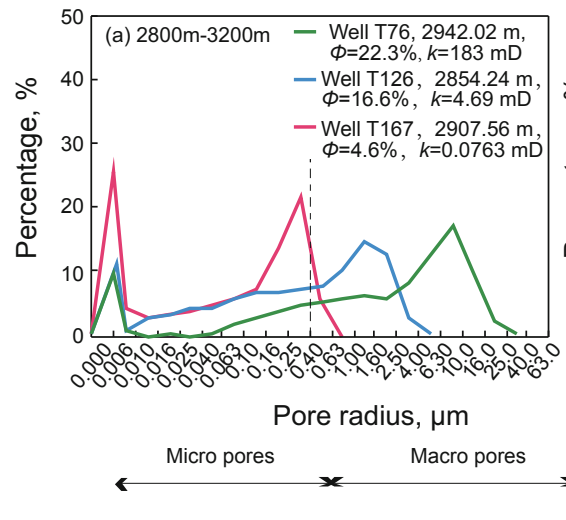

— Anomalously high porosity sandstones

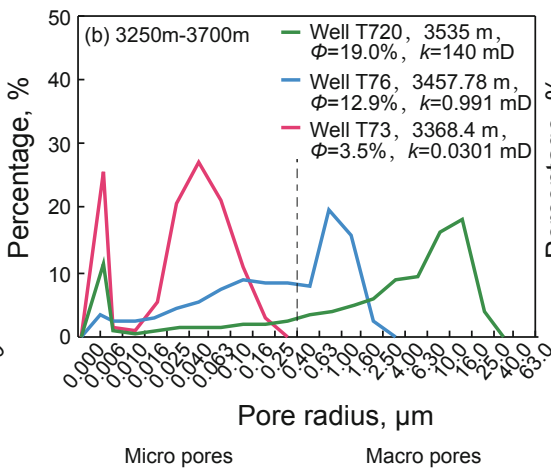

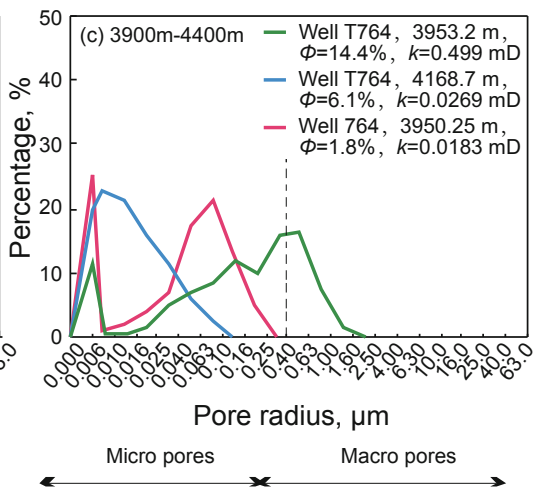

— Low porosity sandstones

Fig. 10 Pore-throat radius distribution of Paleogene $\mathrm{Es}_{4}-\mathrm{Es}_{3}{ }^{\mathrm{z}}$ reservoirs with different porosity levels in different AHP development intervals

\section{Genesis of AHP zones}

\subsection{Diagenetic environment and mineral dissolution}

\subsubsection{Diagenetic environment}

Feldspar dissolution, carbonate dissolution, authigenic kaolinite and quartz cements indicate that reservoirs experienced an acidic diagenetic environment; and quartz dissolution, feldspar overgrowths, carbonate cements are symbols that reservoirs experienced an alkaline diagenetic environment (Zhou et al, 2011). With extensive feldspar dissolution and weak quartz dissolution in Paleogene reservoirs, we focus on the acidic diagenetic environment that is critical to secondary pores.

\section{1) Fluid inclusions}

Quartz overgrowths are common in reservoirs and their thickness generally ranges from $1 \mu \mathrm{m}$ to $50 \mu \mathrm{m}$. As pressure dissolution was weak, the quartz cements probably mainly originate from feldspar dissolution (Yuan et al, 2013a). $T_{\mathrm{h}}$ of fluid inclusions in quartz overgrowths concentrates in $100{ }^{\circ} \mathrm{C}$ $-130^{\circ} \mathrm{C}$ and $160{ }^{\circ} \mathrm{C}-180^{\circ} \mathrm{C}$ (Table 2), respectively, indicating that reservoirs experienced two stages of feldspar dissolution and product precipitation in the diagenetic process. This can also be verified by the two stages of quartz overgrowths in thin sections (Fig. 5(g)). The salinity of fluid inclusions usually exceeds $10 \%$. The high $T_{\mathrm{h}}$ and salinity indicate a weak influence of meteoric water on feldspar leaching (Table 2), so we conclude that feldspar dissolution and authigenic quartz cementation in $\mathrm{Es}_{4}-\mathrm{Es}_{3}{ }^{\mathrm{z}}$ reservoirs occurred in a deep burial diagenetic environment.

Table 2 Fluid inclusions data of quartz overgrowths in Paleogene $\mathrm{Es}_{4}$ reservoirs in the Shengtuo area (Data from the Geological Scientific Research Institute of SINOPEC Shengli Oilfield Company)

\begin{tabular}{cccccccccc}
\hline Well No. & Depth, $\mathrm{m}$ & Strata & Host minerals & Type & $\begin{array}{c}\text { Size, } \\
\mu \mathrm{m}\end{array}$ & $\begin{array}{c}\text { Vapor phase, } \\
\text { vol.\% }\end{array}$ & $T_{\mathrm{h}},{ }^{\circ} \mathrm{C}$ & $T_{\text {ice, }}{ }^{\circ} \mathrm{C}$ & $\begin{array}{c}\text { Salinity, } \\
\% \mathrm{NaCl}\end{array}$ \\
\hline Tuo719 & 3562.1 & $\mathrm{Es}_{4}{ }^{\mathrm{s}}$ & Quartz overgrowth & Salt-water & 7 & 6 & 103.7 & -10.4 & 14.4 \\
Tuo719 & 3562.1 & $\mathrm{Es}_{4}{ }^{\mathrm{s}}$ & Quartz overgrowth & Salt-water & 4 & 5 & 124.4 & -8.0 & 11.7 \\
Tuo719 & 3562.1 & $\mathrm{Es}_{4}{ }^{\mathrm{s}}$ & Quartz overgrowth & Salt-water & 7 & 10 & 128.1 & -6.9 & 10.4 \\
Tuo719 & 3562.1 & $\mathrm{Es}_{4}{ }^{\mathrm{s}}$ & Quartz overgrowth & Salt-water & 5 & 7 & 179.6 & -13.5 & 17.3 \\
Tuo762 & 3451 & $\mathrm{Es}_{4}{ }^{\mathrm{s}}$ & Quartz overgrowth & Salt-water & 6 & 9 & 168.7 & -6.2 & 9.5 \\
\hline
\end{tabular}

\section{2) Fluid pressure}

With disequilibrium compaction, hydrocarbon generation and clay dehydration, fluid overpressure developed in $\mathrm{Es}_{4}-\mathrm{Es}_{3}{ }^{\mathrm{z}}$ reservoirs in the Shengtuo area, especially in the sublacustrine fans (Zhang et al, 2009). According to the measured fluid pressure data, weak fluid overpressure began to develop at 2,000 $\mathrm{m}$ in the northern steep slope zone, and medium-strong fluid overpressure developed commonly when the burial depth exceeded 2,200 m (Fig. 11). According to evolution history of fluid pressure in the Shengtuo area (Fig. 12), fluid overpressure began to develop in $\mathrm{Es}_{4}$ reservoirs at $40 \mathrm{Ma}$ and in $\mathrm{Es}_{3}{ }^{\mathrm{z}}$ reservoirs at $14 \mathrm{Ma}$ (Tang, 2007; Sun, 2010) when the reservoir burial depth exceeded $2,200 \mathrm{~m}$. In the source rocks, kerogen began to generate large amounts of organic acids and $\mathrm{CO}_{2}$ when the depth exceeded $2,000 \mathrm{~m}$. So when significant organic acids and $\mathrm{CO}_{2}$ were expelled into the reservoirs, overpressure was generated. This suggested that feldspar dissolution occurred in a relatively closed diagenetic system with fluid overpressure.

\section{3) Thermal evolution of organic matter and acidic fluid source}

From $80{ }^{\circ} \mathrm{C}$ to $138^{\circ} \mathrm{C}$, the kerogen vitrinite reflectance 


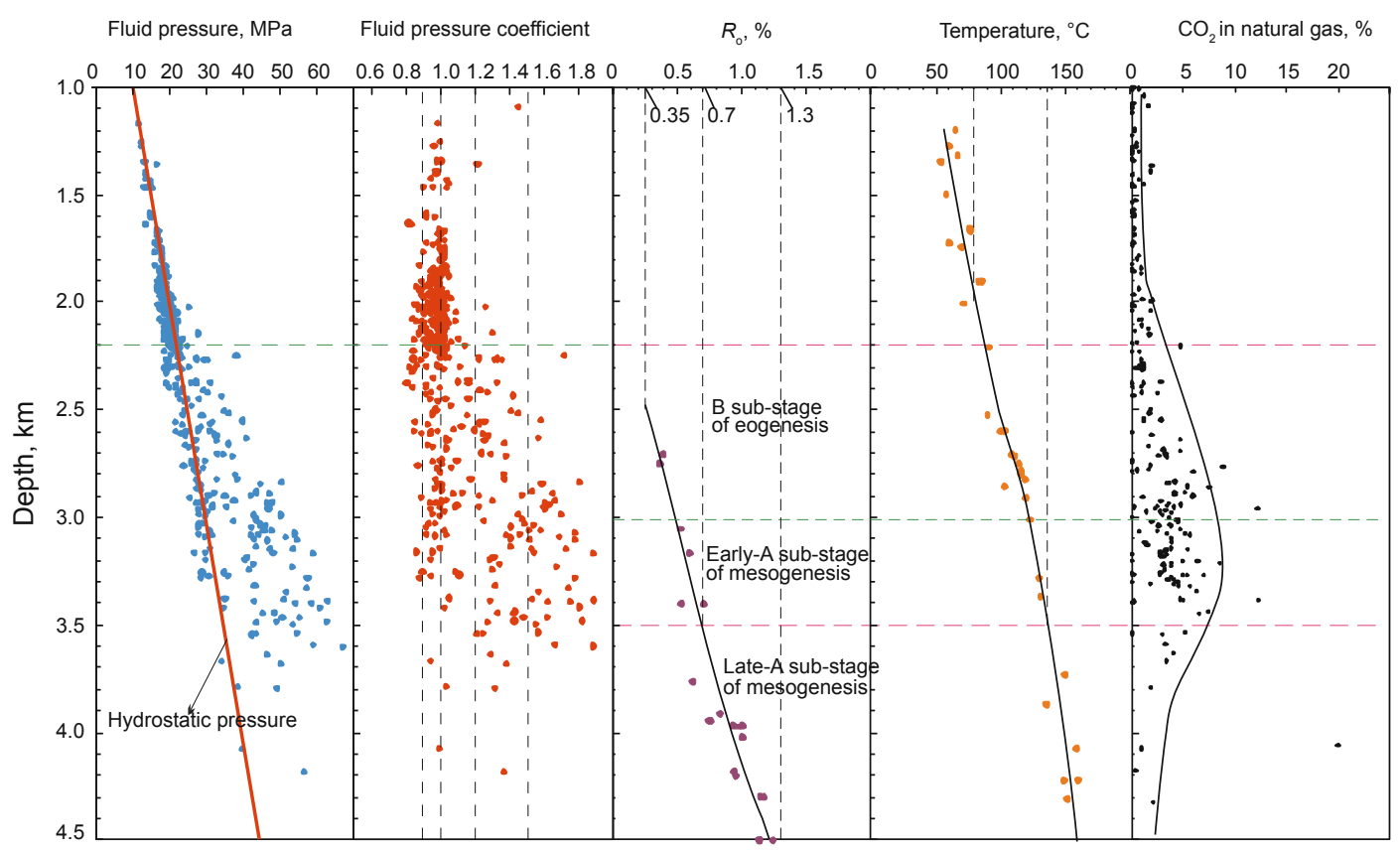

Fig. 11 Distribution of measured fluid pressure, kerogen vitrinite reflectance $\left(R_{\mathrm{o}}\right)$, formation temperature and $\mathrm{CO}_{2}$ contents in the northern steep slope zone of the Dongying Sag

$\left(R_{\mathrm{o}}\right)$ is $0.35 \%-0.70 \%$ in the diagenetic stage from period $\mathrm{B}$ of the eogenetic stage to sub-period A1 of the mesogenetic stage. Thermal evolution of organic matter can generate large amounts of organic acids and $\mathrm{CO}_{2}$ (Fig. 11). These acidic fluids expelled into reservoirs from source rocks by compaction and overpressure related to hydrocarbon generation and clay dehydration should be the most likely source of acids for stage-I feldspar leaching. The stage-II feldspar dissolution mainly occurred at $160{ }^{\circ} \mathrm{C}$ to $180{ }^{\circ} \mathrm{C}$. When the temperature exceeded $160^{\circ} \mathrm{C}$, the degradation of organic matter in source rocks generated $\mathrm{CO}_{2}$. Meanwhile, the organic acid generated earlier experienced intense decarboxylation, and its concentration decreased sharply. $\mathrm{CO}_{2}$ generated in these processes diffused into the pore water and released $\mathrm{H}^{+}$, which controlled the $\mathrm{pH}$ and provided acidic fluids for the stage II feldspar leaching (Surdam et al, 1989). $\mathrm{CO}_{2}$ detected in the fluid inclusions in quartz overgrowths also suggests the formation of these cements in the presence of $\mathrm{CO}_{2}$ (Chen et al, 2010). In addition, in the oilgas reservoirs below $4,000 \mathrm{~m}$, the low $\mathrm{CO}_{2}$ content indicates the consumption of $\mathrm{CO}_{2}$ by feldspar dissolution (Fig. 11).

\subsubsection{Little porosity enhancement from feldspar dissolution}

Whether feldspar dissolution can effectively increase the reservoir porosity depends on whether the dissolution byproducts can be removed from the dissolution area. The feldspar dissolution in $\mathrm{Es}_{4}-\mathrm{Es}_{3}{ }^{\mathrm{z}}$ reservoirs occurred in a relatively closed diagenetic system with high temperature and salinity. We can also determine this from microscopy, which shows that if the feldspar dissolution is weak, the dissolution byproducts are less; if feldspar dissolution is abundant, the dissolution byproducts are abundant. To objectively evaluate the impact of feldspar dissolution on reservoir porosities, using interactive image analysis techniques, quantitative statistics were collected for the contents of feldspar pores, authigenic kaolinite and quartz overgrowths with red epoxy resin-impregnated thin sections. Fig. 13 shows that, without calibration of kaolinite micropores, the difference between the contents of feldspar pores and byproducts is generally below 0 . $\mathrm{He}$ and Nan (2004) found authigenic kaolinite microporosity to be $25 \%-50 \%$. With an average value of $37 \%$, we made the correction of kaolinite content. Then, the difference between contents of feldspar pores and byproducts was generally less than $0.25 \%$, and usually very close to $0 \%$ (Fig. 13). Transfer of the dissolution byproducts out of the sandstones may take place during dissipation of overpressure, resulting in some enhanced porosity. However, the data demonstrate that, in a relatively closed system, significant feldspar pores exist, but the feldspar dissolution has little impact on porosity. The main function of feldspar dissolution is converting primary pores into isovolumetric feldspar secondary pores and micropores in authigenic clays.

In relatively closed diagenetic systems, the feldspar dissolution products cannot be effectively removed from the sandstones. Precipitation occurs in forms of authigenic clay minerals (kaolinite and illite) and quartz cements in situ, and the maximum enhanced porosity by dissolution of one unit volume of K-feldspar, albite and anorthite is $13 \%, 7 \%$ and $4 \%$, respectively (Giles and de Boer, 1990). The maximum amount of feldspar pores in reservoirs in the Shengtuo area is about $3 \%$, then, the maximum enhanced porosity due to feldspar dissolution (suppose all are $\mathrm{K}$-feldspars) is just $0.4 \%$ $(3 \% \times 13 \%=0.4 \%)$, which is in consistent with the statistical data.

\subsubsection{Little dissolution of carbonate minerals}

Based on the negative relationship between core porosity and the amount of carbonate cements, Zhong et al (2003), Zhu et al (2007) and Zhang et al (2007) argued that the low content of carbonate cements in the high porosity reservoirs in the Shengtuo area originated from significant dissolution of 


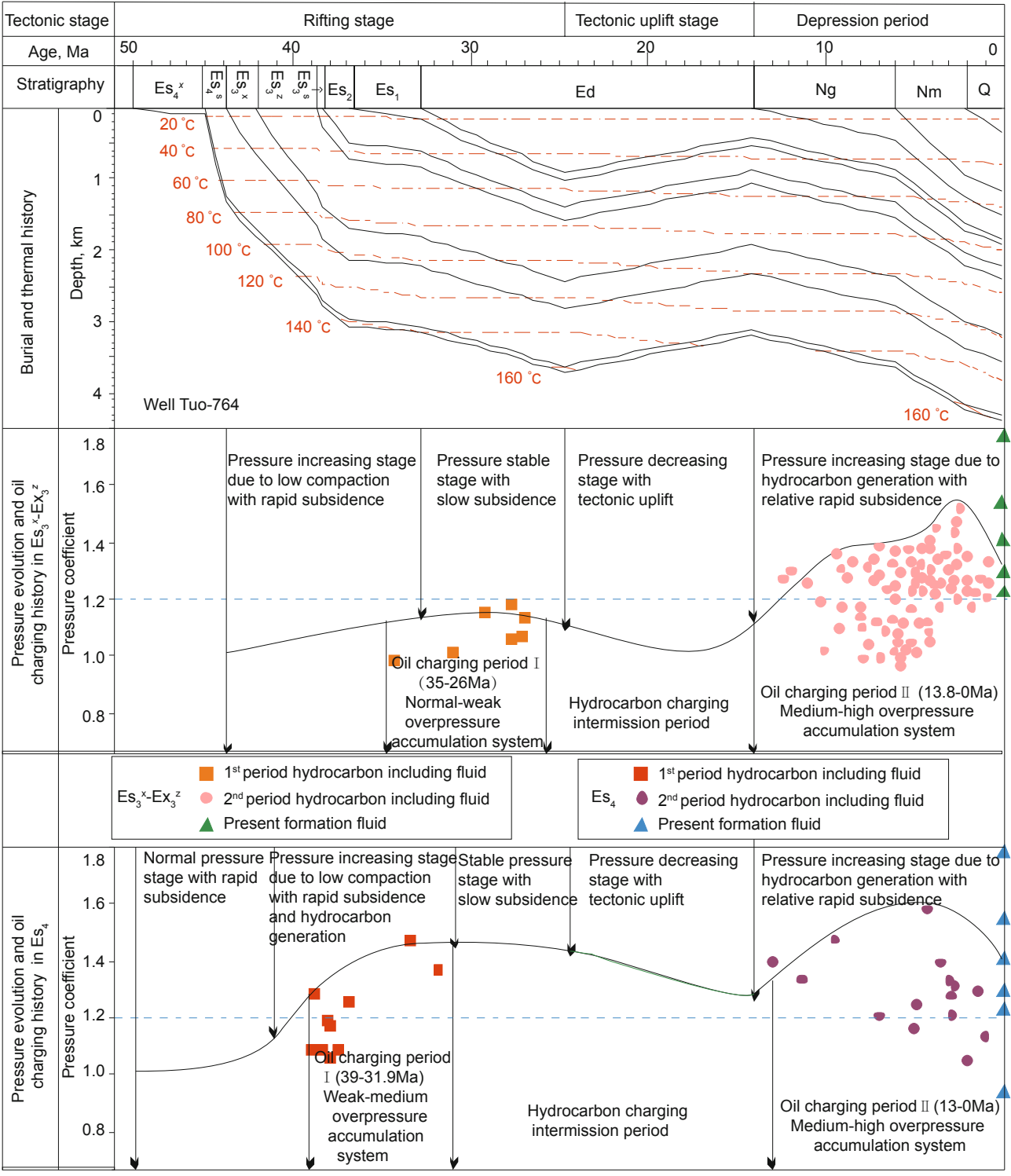

Fig. 12 Burial and thermal history, fluid pressure evolution history and hydrocarbon charging history of sublacustrine fans in the Shengtuo area (Data of hydrocarbon charging history and fluid pressure evolution history from Cai et al (2009) and Sun (2010))

carbonate cements, and the significant intergranular pores are mainly carbonate cement dissolution pores.

With observation of nearly 200 thin sections and red epoxy resin-impregnated thin sections and 55 SEM samples in the Shengtuo area, we found carbonate cements occur as connected patches (Fig. 5(a)), single crystal (Fig. 5(g)) or grain coating carbonate (Fig. 5(c)-(f)), and commonly exhibit euhedral crystal faces where abutting open pore space (Fig. 5(h)). The euhedral dolomite coated with stage-II quartz overgrowths (Fig. 5(g)) suggests that carbonate minerals were not leached when stage-II feldspar dissolution and quartz cement precipitation took place. In addition, detrital carbonate grains and grain coating carbonate cements show no evidence of dissolution (Fig. 5(c)-(f)). The carbonate overgrowths are often found accompanying detrital carbonate grains (Fig. 5(b)). However, feldspar grains wrapped by early grain coating carbonate cements or close to detrital carbonate grains were dissolved extensively (Fig. 5(c)-(f)).
These phenomena demonstrate that carbonate cements and detrital carbonate grains were not noticeably corroded. As no evidence shows significant dissolution of carbonate cements, a large number of intergranular pores are likely to be primary intergranular pores instead of carbonate cement dissolution pores. The most likely reason for the negative relationship between porosity and percent carbonate cements should be the carbonate cementation degree, rather than the carbonate cement dissolution degree.

About the selective dissolution phenomena between feldspars and carbonate minerals, we explain this as follows:

1) At depths of 2,500-3,500 $\mathrm{m}$, the formation temperature in the Dongying Sag is about $100{ }^{\circ} \mathrm{C}-130{ }^{\circ} \mathrm{C}$, and the $R_{\mathrm{o}}$ of kerogen in source rocks is $0.35 \%-0.70 \%$, which are beneficial for the generation and preservation of organic acids. Organic acids control the alkalinity of pore water, and the $\mathrm{pCO}_{2}$ is relatively high (Fig. 11). In such an organic acids-carbonic acid- $-\mathrm{pCO}_{2}-$ carbonate minerals-aluminum silicate minerals 


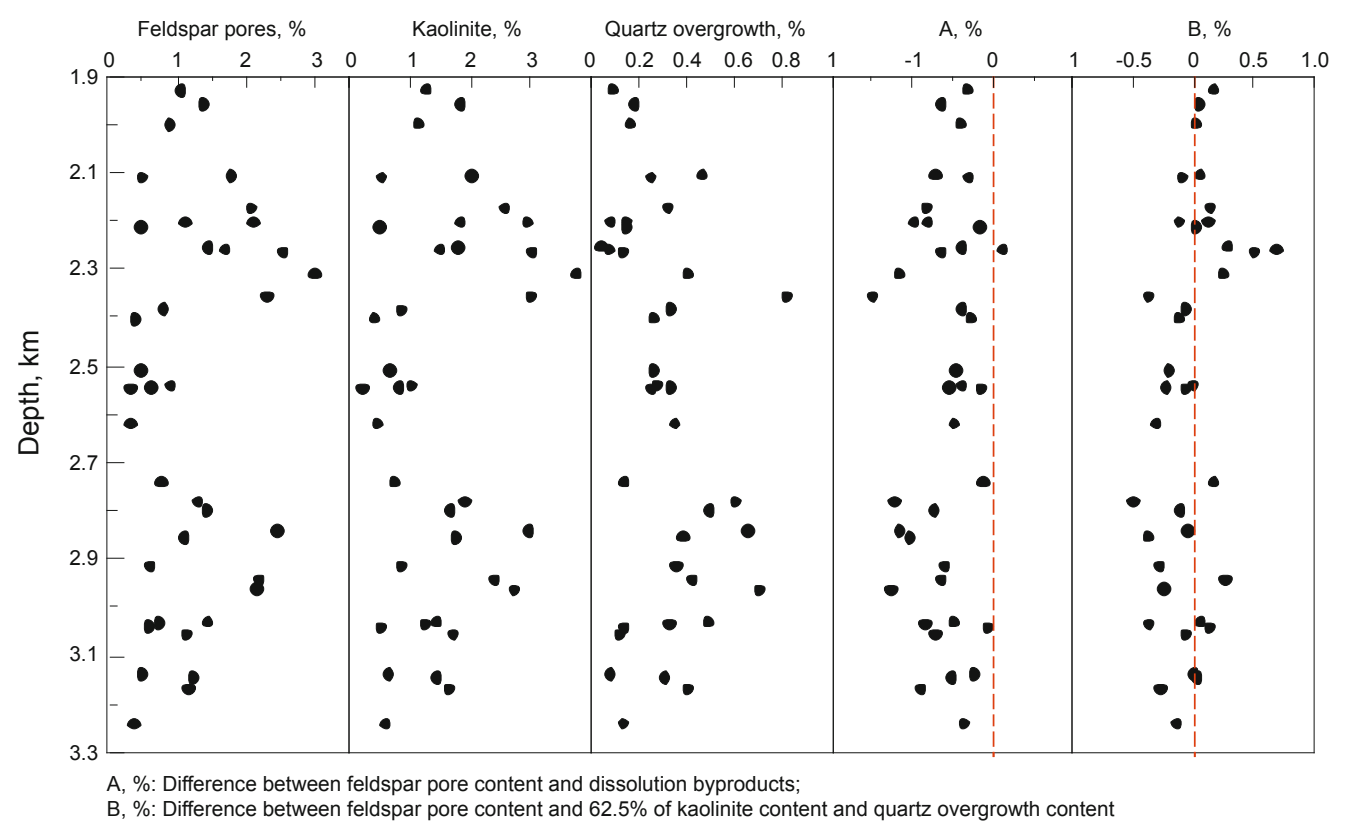

Fig. 13 Amount of feldspar pores, dissolution products, and their differences in $\mathrm{Es}_{4}-\mathrm{Es}_{3}{ }^{2}$ reservoirs

buffer system, the carbonate minerals tend to be precipitated rather than to be corroded, but the feldspars tend to be leached (Surdam et al, 1989).

2) Thick gypsum and salt layers and carbonate layers exist in the Palaeogene $\mathrm{Es}_{4}$ Formation, and suggest a high salinity and strong alkalinity of the sedimentary water (Wang, 2010). Salinity data of fluid inclusions in quartz overgrowths indicate the leaching of feldspars by acidic fluids with high salinity (Table 2). The modern pore water in reservoirs has high salinity, and the concentration of $\mathrm{Ca}^{2+}$ and $\mathrm{Mg}^{2+}$ is high (Fig. 14). High salinity and high concentration of $\mathrm{Ca}^{2+}$ and $\mathrm{Mg}^{2+}$ probably inhibit carbonate dissolution, and promote its precipitation due to the common-ion effect.

3) The main source rocks in the Dongying Sag contain high percentage of carbonate minerals (up to $50 \%$ ), feldspars and other unstable minerals (Qian et al, 2009). Fine unstable minerals with high specific surface area in source rocks reacted first with the organic acids that were released during thermal evolution of organic matter due to their proximity (Giles and Marshall, 1986). In addition, the initial salinity of pore water was high, so fluid expelled from source rocks into reservoirs would be rich in various ions. As the fluid with high salinity and weak acidity entered into the reservoirs, its acidity decreased further, in such condition, the carbonate minerals tended to be precipitated, rather than be dissolved (Zeng, 2001).

4) The study by Song and Huang (1990) shows that carbonate minerals may precipitate at a $\mathrm{pH}$ between 5 and 6 , although most scholars argued that carbonate minerals begin to precipitate when $\mathrm{pH}$ exceeds 8.4. In addition, the calculation results by Huang et al (2009a) show that, for carbonate dissolution in deep buried reservoirs $(>3,000 \mathrm{~m})$, the $\mathrm{pH}$ of fluid should be lower than 5 . However, $\mathrm{CaCl}_{2}$ type pore water with high salinity of the relatively stagnant environment in the Shengtuo area is generally weakly acidic with $\mathrm{pH}$ between 6 and 7 (Fig. 14), which is not favorable for carbonate dissolution in deep burial.
5) The calculation of Meshri (1986) shows that at $25^{\circ} \mathrm{C}$ and 1 bar, the Gibbs free energy $(\Delta G)$ for leaching of anorthite and $\mathrm{K}$-feldspar by acetic acid to form kaolinite is $-36.9 \mathrm{~kJ} /$ $\mathrm{mol}$ and $-4.28 \mathrm{~kJ} / \mathrm{mol}$, and $\Delta G$ of the reaction between calcite and acetic acid is $+11.20 \mathrm{~kJ} / \mathrm{mol}$. Meanwhile, as temperature and pressure increase, $\Delta G$ of reaction between organic acid and feldspars decreases (Huang et al, 2009b), while as temperature increases, the solubility of carbonate minerals decreases sharply. Therefore, in a relatively closed diagenetic environment with high temperature, the organic acids tend to dissolve feldspars rather than carbonate minerals.

\subsection{Geological processes in favor of porosity preservation}

\subsubsection{Sedimentary facies}

Statistical data show that sedimentary facies in the Shengtuo area have significant influence on the reservoir porosity. On the whole, porosities of sublacustrine fan reservoirs are higher than those of nearshore subaqueous fans, which might be related to the fluid overpressure in sublacustrine fans. For example, in AHP development intervals I and II, reservoirs in sublacustrine fans have an average porosity of $15.03 \%$ and $10.72 \%$, while the average porosity of reservoirs in nearshore subaqueous fans is just $10.43 \%$ and $6.43 \%$ (Table 3 ). In sublacustrine fans, porosities of reservoirs in braided channels in the mid-fan are the best, followed by porosities of main channels innerfan, and porosities of outer fan and inter-channels in midfan are the worst. In nearshore subaqueous fans, porosities of reservoirs in middle-front of fan body are the best, porosities of reservoirs in root of fan body and fan edge are worse (Table 3).

\subsubsection{Fluid overpressure}

The fluid pressure in the $\mathrm{Es}_{4}$ formation experienced five stages: 1) normal pressure stage with rapid subsidence at 49$40 \mathrm{Ma}, 2)$ pressure increase stage due to low compaction with 


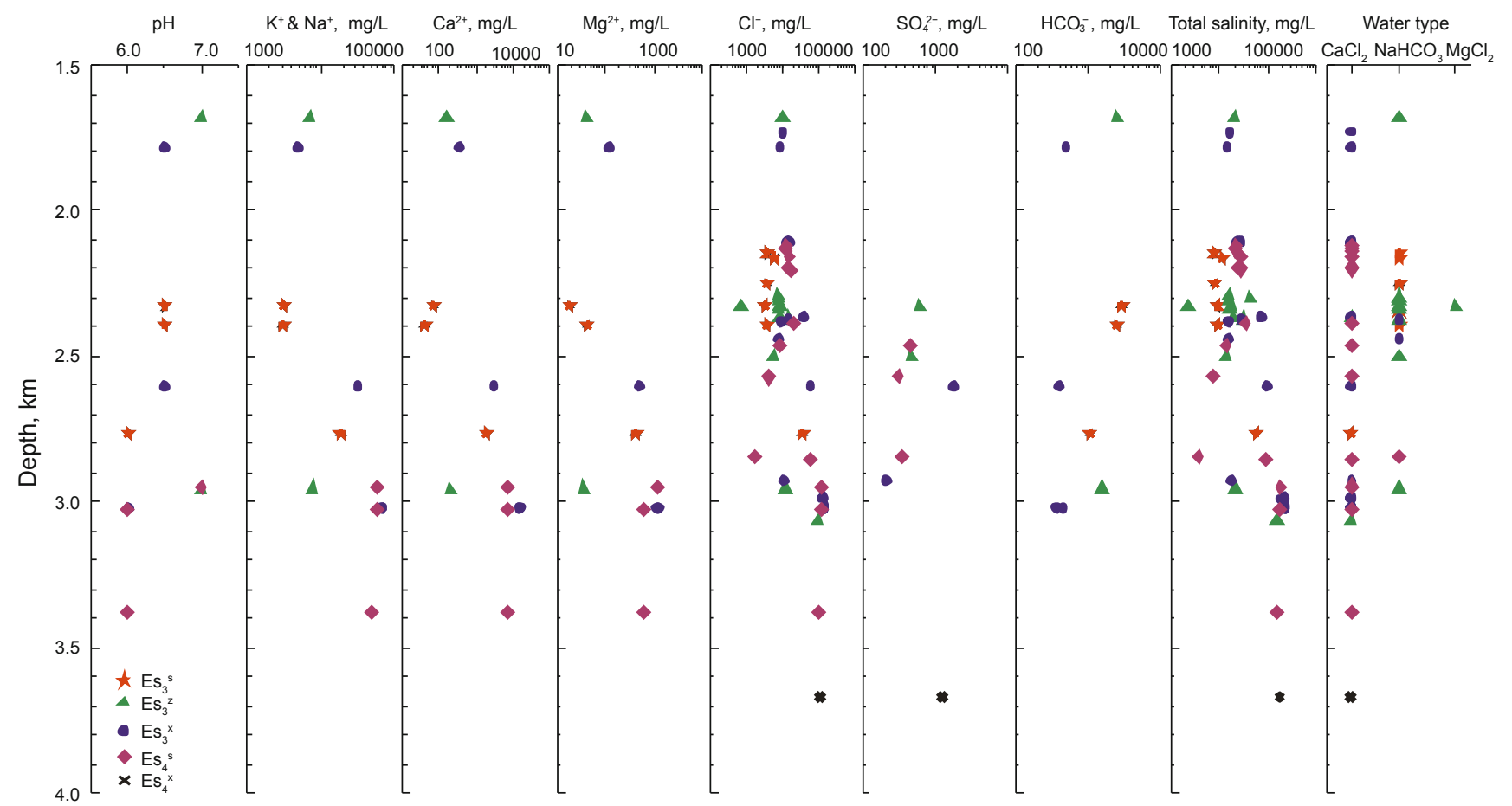

Fig. 14 Characteristics of pore water in Palaeogene $\mathrm{Es}_{4}-\mathrm{Es}_{3}$ formation

Table 3 Reservoir porosity of different sedimentary facies (microfacies), fluid pressure and oiliness in different AHP development intervals

\begin{tabular}{|c|c|c|c|c|c|c|c|c|c|c|c|c|c|c|c|c|}
\hline \multirow{3}{*}{\multicolumn{2}{|c|}{$\begin{array}{r}\text { Controlling } \\
\text { factors } \\
\text { Porosity } \\
\text { intervals }\end{array}$}} & \multicolumn{9}{|c|}{ Sedimentray facies } & \multicolumn{3}{|c|}{ Fluid pressure } & \multicolumn{3}{|c|}{ Oiliness of sandstones } \\
\hline & & \multicolumn{4}{|c|}{ Nearshore subaqueous fan } & \multicolumn{5}{|c|}{ Sublacustrine fan } & \multirow{2}{*}{$\begin{array}{c}\text { Normal } \\
\text {-weak } \\
\text { over- } \\
\text { pressure }\end{array}$} & \multirow{2}{*}{$\begin{array}{c}\text { Medium } \\
\text { over- } \\
\text { pressure }\end{array}$} & \multirow{2}{*}{$\begin{array}{c}\text { Strong } \\
\text { over- } \\
\text { pressure }\end{array}$} & \multirow[b]{2}{*}{$\begin{array}{l}\text { No oil, } \\
\text { oil trace }\end{array}$} & \multirow[b]{2}{*}{$\begin{array}{c}\text { Oil } \\
\text { spot }\end{array}$} & \multirow{2}{*}{$\begin{array}{c}\text { Oil } \\
\text { immersion, } \\
\text { oil bearing }\end{array}$} \\
\hline & & Total & $\begin{array}{c}\text { Root of } \\
\text { fan } \\
\text { body }\end{array}$ & $\begin{array}{l}\text { Middle- } \\
\text { front of } \\
\text { fan body }\end{array}$ & Fan edge & Total & $\begin{array}{c}\text { Main } \\
\text { water } \\
\text { channel }\end{array}$ & $\begin{array}{l}\text { Braided } \\
\text { channel }\end{array}$ & $\begin{array}{c}\text { Inter } \\
\text { channel }\end{array}$ & Fan edge & & & & & & \\
\hline \multirow{4}{*}{$\begin{array}{l}\text { Abnormally } \\
\text { high porosity } \\
\text { development } \\
\text { interval I }\end{array}$} & Min, $\%$ & 1.0 & 1.0 & 2.6 & 1.9 & 1.4 & 3.5 & 1.4 & 1.7 & 1.8 & 1.0 & 1.8 & 1.4 & 1.0 & 1.4 & 2.9 \\
\hline & Max, \% & 22.0 & 19.2 & 22.0 & 23.6 & 29.5 & 19.7 & 29.5 & 21.1 & 19.9 & 27.0 & 19.9 & 29.5 & 26.9 & 23.8 & 29.5 \\
\hline & Ave, $\%$ & 10.43 & 7.46 & 12.92 & 6.62 & 15.03 & 10.33 & 17.70 & 8.34 & 9.02 & 11.20 & 11.62 & 15.39 & 10.22 & 11.35 & 16.55 \\
\hline & Sample No. & 516 & 50 & 302 & 164 & 873 & 78 & 595 & 27 & 173 & 426 & 294 & 669 & 363 & 425 & 601 \\
\hline \multirow{4}{*}{$\begin{array}{l}\text { Abnormally } \\
\text { high porosity } \\
\text { development } \\
\text { interval II }\end{array}$} & Min, $\%$ & 0.7 & 0.7 & 1.8 & 2.9 & 1.1 & 1.5 & 1.6 & 1.2 & 1.1 & 0.7 & 1.1 & 1.2 & 0.7 & 1.3 & 1.5 \\
\hline & $\operatorname{Max}, \%$ & 20.9 & 8.8 & 20.9 & 20.9 & 32.9 & 28.1 & 32.9 & 16.8 & 19.9 & 11.4 & 22.1 & 32.9 & 22.1 & 28.1 & 32.9 \\
\hline & Ave, $\%$ & 6.43 & 3.57 & 8.60 & 11.06 & 10.72 & 9.66 & 12.55 & 6.89 & 7.16 & 5.27 & 10.18 & 11.92 & 6.44 & 10.02 & 13.63 \\
\hline & Sample No. & 171 & 71 & 70 & 30 & 793 & 166 & 451 & 93 & 83 & 142 & 544 & 278 & 345 & 293 & 326 \\
\hline \multirow{4}{*}{$\begin{array}{l}\text { Abnormally } \\
\text { high porosity } \\
\text { development } \\
\text { interval III }\end{array}$} & Min, $\%$ & - & - & - & - & 1.8 & - & 1.8 & - & - & - & 1.8 & - & 1.8 & 6.1 & 8.6 \\
\hline & Max, \% & - & - & - & - & 22.3 & - & 22.3 & - & - & - & 22.3 & - & 13.9 & 22.3 & 21.7 \\
\hline & Ave, $\%$ & - & - & - & - & 15.12 & - & 15.12 & - & - & - & 15.12 & - & 9.56 & 14.71 & 16.22 \\
\hline & Sample No. & - & - & - & - & 88 & - & 88 & - & - & - & 88 & - & 11 & 13 & 64 \\
\hline
\end{tabular}

rapid subsidence and hydrocarbon generation at 40-31.9 Ma, 3) stable pressure stage with slow subsidence at 31.9-24.6 $\mathrm{Ma}, 4)$ pressure decrease stage with tectonic uplifting at 24.6$14 \mathrm{Ma}$ and 5) pressure increase stage due to hydrocarbon generation with relatively rapid subsidence at $14-0 \mathrm{Ma}$ (Fig. 12) (Zhang et al, 2009; Sun, 2010).

Before $13 \mathrm{Ma}$, fluid pressure in sublacustrine fans in $\mathrm{Es}_{3}$ was generally normal, but with weak overpressure development at 35-24.6 Ma. Moderate-strong overpressure began to develop after about $13 \mathrm{Ma}$ (Fig. 12) (Cai et al, 2009). When fluid overpressure began to develop, the burial depths of sublacustrine fan reservoirs in $\mathrm{Es}_{3}$ and $\mathrm{Es}_{4}$ are always shallower than 2,200 $\mathrm{m}$. The shallow development of fluid overpressure retarded compaction during deeper burial and pores in reservoirs were preserved to greater depths.

Data in Table 3 show that as fluid overpressure 
increases, the average porosity of reservoirs in the three AHP development intervals increases significantly. In AHP development interval I, reservoirs with normal-weak pressure have an average porosity of $11.20 \%$, those with middle fluid overpressure have an average porosity of $11.62 \%$, and those with high fluid overpressure have an average porosity of $15.39 \%$ (Table 3). In AHP development interval II, reservoirs with normal fluid pressure and weak fluid overpressure have an average porosity of $5.27 \%$, those with middle overpressure have an average porosity of $10.18 \%$, and those with strong overpressure have an average porosity of $11.92 \%$ (Table 3 ). In AHP development interval III, all reservoirs have middle fluid overpressure, and the average porosity is up to $15.12 \%$ (Table 3 ). So we can say that the shallow development of fluid overpressure effectively retarded the compaction, leading to point contact and line-point contact of detrital grains in deeply buried reservoirs (Fig. 9(a), (g)). Thus, shallow development of fluid overpressure is of significance to the development of AHP zones in deeply buried strata.

\subsubsection{Hydrocarbon emplacement}

Hydrocarbon emplacement in $\mathrm{Es}_{4}$ reservoirs occurred mainly at 39-31.9 Ma and 13-0 Ma (Fig. 12) (Sun, 2010). Hydrocarbon emplacement in $\mathrm{Es}_{3}{ }^{\mathrm{x}}-\mathrm{Es}_{3}{ }^{\mathrm{z}}$ reservoirs occurred mainly at 38.2-33.5 Ma and 11.5-0 Ma (Fig. 12) (Cai et al, 2009), and the second stage is more important. When hydrocarbon emplacement took place, the reservoirs were always shallower than $2,500 \mathrm{~m}$. The early hydrocarbon emplacement inhibited carbonate cementation during late burial and reservoir pores were preserved to deeper depth.

Data in Table 3 show that as oil saturation increases, the average porosity of reservoirs in the three AHP development intervals increases sharply, and carbonate cement content decreases significantly. In AHP development interval I, reservoirs with no oil, fluorescence or oil trace have an average porosity of $10.22 \%$ and an average carbonate cement content of $11.22 \%$. Reservoirs with oil spots have an average porosity of $11.35 \%$ and an average carbonate cement content of $12.32 \%$. Oil saturated or oil rich reservoirs have an average porosity of $16.55 \%$ and an average carbonate cement content of $6.99 \%$ (Table 3). In AHP development interval II, reservoirs with no oil, fluorescence, or just a trace of oil have an average porosity of $6.44 \%$ and an average carbonate cement content of $9.95 \%$. Reservoirs with oil spots have an average porosity of $10.02 \%$ and an average carbonate cement content of $15.60 \%$. Oil saturated or oil rich reservoirs have an average porosity of $13.63 \%$ and an average carbonate cement content of $5.15 \%$ (Table 3). In AHP development interval III, reservoirs with no oil, fluorescence, or oil traces have an average porosity of $9.56 \%$ and an average carbonate cement content of $14.20 \%$. Reservoirs with oil spot have an average porosity of $14.71 \%$ and an average carbonate cement content of $10.40 \%$. Oil saturated or oil rich reservoirs have an average porosity of $16.22 \%$ and an average carbonate cement content of $9.82 \%$ (Table 3 ). So we can say that the early hydrocarbon emplacement effectively inhibited carbonate cementation and that early hydrocarbon emplacement is of significance to the development of AHP zones in deeply buried strata.

\section{Conclusions}

1) Three AHP zones developed in Palaeogene $\mathrm{Es}_{4}-\mathrm{Es}_{3}{ }^{\mathrm{z}}$ reservoirs in the Shengtuo area of the Dongying Sag, at depths of 2,800-3,200 m, 3,250-3,700 $\mathrm{m}$ and 3,900-4,400 m, respectively.

2) AHP zones at depths of 2,800-3,200 $\mathrm{m}$ and 3,250-3,700 $\mathrm{m}$ are visible pore primary AHP zones, with visible primary intergranular pores dominating. AHP zones at the depth of 3,900-4,400 $\mathrm{m}$ are micropores primary AHP zones, with micropores in matrix dominating.

3) In the relatively closed diagenetic system with high temperature and salinity, burial dissolution contribute little to the AHP zone due to low porosity enhancement by feldspar dissolution and little dissolution of carbonate cements. Reservoirs in braided channels of middle fans in sublacustrine fans and reservoirs in middle-front of fan bodies of nearshore subaqueous fans provided the basis for the development of AHP zones. Shallow development of fluid overpressure and early hydrocarbon emplacement preserved high porosity in deep layers by inhibiting compaction and carbonate cementation effectively during deep burial. Thus, the favorable exploration targets should be reservoirs with good primary porosity that experienced fluid overpressure developed from shallow layers, early hydrocarbon emplacement, and good preservation during later burial.

\section{Acknowledgements}

This study was financially supported by the National Natural Science Foundation of China (No. U1262203, No. 41102058), a National Science and Technology Special Grant (No. 2011ZX05006-003), and Foundation for the Author of National Excellent Doctoral Dissertation of China. We also thank the following individuals and institutions: Jon Gluyas of Durham University, Meng Yuanlin of Northeast Petroleum University, Zhu Guohua in the Hangzhou Institute of Petroleum Geology, CNPC, and reviewers of this manuscript. The Shengli Oilfield Company of SINOPEC provided all the related core samples and some geological data.

\section{References}

An J. The study of sedimentary reservoirs of sand-conglomerate bodies in the $\mathrm{Es}_{3}-\mathrm{Es}_{4}$ Members in the Shengtuo area. Master Thesis. China University of Petroleum (East China). 2010 (in Chinese)

Berger A, Gier S and Krois P. Porosity-preserving chlorite cements in shallow-marine volcaniclastic sandstones: Evidence from Cretaceous sandstones of the Sawan gas field, Pakistan. AAPG Bulletin. 2009. 93(5): 595-615

Bloch S, Lander R H and Bonnell L. Anomalously high porosity and permeability in deeply buried sandstone reservoirs: Origin and predictability. AAPG Bulletin. 2002. 86(2): 301-328

Cai L M, Chen H H, Li C Q, et al. Reconstruction of the paleo-fluid potential field of $\mathrm{Es}_{3}$ in the Dongying Sag of the Jiyang Depression with systematic fluid inclusion analysis. Oil \& Gas Geology. 2009. 30(1): 17-24 (in Chinese)

Cao Y C, Yuan G H, Li X Y, et al. Types and characteristics of anomalously high porosity zones in Paleogene mid-deep buried reservoirs in the northern slope, Dongying Sag. Acta Petrolei Sinica. 
2013. 34(4): 683-691 (in Chinese)

Chen G J, Du G C, Zhang G C, et al. Chlorite cement and its effect on the reservoir quality of sandstones from the Panyu low-uplift, Pearl River Mouth Basin. Petroleum Science. 2011. 8: 143-150

Chen X, Zhong J H, Yuan J, et al. Development and formation of Paleogene kaolinite, Bonan Subsag. Petroleum Exploration and Development. 2009. 36(4): 456-462 (in Chinese)

Chen Y, Lin C Y, Zhang S W, et al. Study on fluid inclusions in deep natural gas reservoirs in Minfeng sub-sag, Dongying Sag. Acta Sedimentologica Sinica. 2010. 28(3): 620-625 (in Chinese)

Ehrenberg S N, Walderhaug O and Bjørlykke K. Carbonate porosity creation by mesogenetic dissolution: Reality or illusion?. AAPG Bulletin. 2012. 96(2): 217-233

Ehrenberg S N. Preservation of anomalously high porosity in deeply buried sandstones by grain-coating chlorite: examples from the Norwegian Continental Shelf. AAPG Bulletin. 1993. 77(7): 12601286

Folk R L, Andrews P B and Lewis D W. Detrital sedimentary rock classification and nomenclature for use in New Zealand. New Zealand Journal of Geology and Geophysics. 1970. 13: 937-968

Gao J G, Gao S X, Wang F H, et al. Characteristics of formation pressure and its influences on reservoirs of the fourth member of the Shahejie Formation in Shengtuo area of Dongying Depression. Petroleum Geology and Recovery Efficiency. 2008. 15(1): 35-38 (in Chinese)

Giles M R and de Boer R B. Origin and significance of redistributional secondary porosity. Marine and Petroleum Geology. 1990. 7: 378-397

Giles M R and Marshall J D. Constraints on the development of secondary porosity in the subsurface: re-evaluation of processes. Marine and Petroleum Geology. 1986. 3: 243-255

He Z X and Nan J X. Atlas of Upper Paleozoic Reservoirs in the Ordos Basin. Beijing: Petroleum Industry Press. 2004. 84 (in Chinese)

Higgs K E, Zwingmann H, Reyes A G, et al. Diagenesis, porosity evolution, and petroleum emplacement in tight gas reservoirs, Taranaki basin, New Zealand. Journal of Sedimentary Research. 2007. 77: 1003-1025

Huang K K, Huang S J, Tong H P, et al. Thermodynamic calculation of feldspar dissolution and its significance on research of clastic reservoir. Geological Bulletin of China. 2009a. 28(4): 474-482 (in Chinese)

Huang S J, Huang K K, Zhang X H, et al. Chemical thermodynamics foundation of retrograde solubility for carbonate: Solution media related to $\mathrm{CO}_{2}$. Journal of Chengdu University of Technology (Science \& Technology Edition). 2009b. 36(5): 457-464 (in Chinese)

Jin Z K, Su K and Su N N. Origin of Jurassic deep burial high-quality reservoirs in the central Junggar Basin. Acta Petrolei Sinica. 2011. 32(1): 25-31 (in Chinese)

Liu H, Jiang Z X, Zhang R F, et al. Gravels in the Daxing conglomerate and their effect on reservoirs in the Oligocene Langgu Depression of the Bohai Bay Basin, North China. Marine and Petroleum Geology. 2012. 29: 192-203

Liu W and Zhu X M. Distribution and genesis of secondary pores in Tertiary clastic reservoir in Southwestern Qaidam Basin. Petroleum Exploration and Development. 2006. 33(3): 315-318 (in Chinese)

Liu Y Y, Yu B S, Zhu J F, et al. Diagenesis and its influence on physical properties in Paleogene clastic reservoir in the West Sag of the beach area, Liaohe Depression. Geoscience. 2009. 23(4): 731-738 (in Chinese)

Luo J L, Morad S, Zhang X L, et al. Reconstruction of the diagenesis of the fluvial-lacustrine-deltaic sandstones and its influence on the reservoir quality evolution-evidence from Jurassic and Triassic sandstones, Yanchang Oil Field, Ordos Basin. Science in China Series D: Earth Sciences. 2002. 45(7): 616-634

Marchand A M E, Smalley P C, Haszeldine R S, et al. Note on the importance of hydrocarbon fill for reservoir quality prediction in sandstones. AAPG Bulletin. 2002. 86(9): 1561-1571

Meng Y L, Gao J J, Liu D L, et al. Diagenetic facies analysis and anomalously high porosity zone prediction of the Yuanyanggou area in the Liaohe Depression. Journal of Jilin University (Earth Science Edition). 2006. 36(2): 227-233 (in Chinese)

Meng Y L, Liang H W, Meng F J, et al. Distribution and genesis of the anomalously high porosity zones in the middle-shallow horizons of the northern Songliao Basin. Petroleum Science. 2010. 7: 302-310

Meshri I D. On the reactivity of carbonic and organic acids and generation of secondary porosity. SEPM Special Publication. 1986. 28: $123-128$

Peng J, Liu J K, Wang Y, et al. Origin and controlling factors of chlorite coatings - an example from the reservoir of $\mathrm{T}_{3} \mathrm{x}$ Group of the Baojie area, Sichuan Basin, China. Petroleum Science. 2009. 6: 376-382

Qian H J, Lu X C, Zhang X F, et al. Spatial paleosalinity distribution and element geochemistry of argillaceous source rocks in the upper part of $4^{\text {th }}$ Member of Tertiary Shahejie Formation in Dongying Sag. Acta Petrologica et Mineralogica. 2009. 28(2): 161-168 (in Chinese)

Song H R and Huang S Y. Crystallized precipitation of carbonate. Carsologica Sinica. 1990. 9(2): 105-118 (in Chinese)

Sun X L. Hydrocarbon charging mechanism and reservoir forming models in the deep formations of the north belt, Dongying Depression. Master's Thesis. China University of Geosciences. 2010 (in Chinese)

Surdam R C, Crossey L J, Hagen E S, et al. Organic-inorganic interactions and sandstone diagenesis. AAPG Bulletin. 1989. 73: $1-23$

Tang J C. The reconstruction of paleo-fluid potential and the study of oil migration and accumulation characteristics of the third member of Shahejie Formation, Dongying Sag. Master's Thesis. China University of Geosciences. 2007 (in Chinese)

Taylor T R, Giles M R, Hathon L A, et al. Sandstone diagenesis and reservoir quality prediction: Models, myths, and reality. AAPG Bulletin. 2010. 94(8): 1093-1132

Wang C and Shao H M. A study on secondary pores of medium combination formation to the west of Daqing Placanticline. Petroleum Geology \& Oilfield Development in Daqing. 1999. 18(5): 5-7 (in Chinese)

Wang Y Z. Genetic mechanisms and evolution models of the Paleogene secondary pore development zone in the North Zone in Dongying Depression. Ph.D. Thesis. China University of Petroleum (East China). 2010 (in Chinese)

Warren E A and Pulham A J. Anomalous porosity and permeability preservation in deeply buried Tertiary and Mesozoic sandstones in the Cusiana field, Llanos Foothills, Colombia. Journal of Sedimentary Research. 2001. 71(1): 2-14

Xiao L H, Meng Y L, Hou C Y, et al. Diagenetic modeling and prediction of secondary pore zone in the deep of the Shengping area in the Songliao Basin. Geological Review. 2003. 49(5): 544-551 (in Chinese)

Yu B S, Dong H L and Ruan Z. Mechanism for calcite dissolution and its contribution to development of reservoir porosity and permeability in the Kela 2 gas field, Tarim Basin, China. Science in China Series D: Earth Sciences. 2008. 51(4): 567-578

Yuan G H, Cao Y C, Xi K L, et al. Feldspar dissolution and its impact on physical properties of Paleogene clastic reservoirs in the northern slope zone of the Dongying Sag. Acta Petrolei Sinica. 2013a. 34(5): 853-866 (in Chinese)

Yuan G H, Cao Y C, Yang T, et al. Porosity enhancement potential through mineral dissolution by organic acids in the diagenetic progress of clastic reservoir. Earth Science Frontiers. 2013b. 20(5): 207-119 (in Chinese)

Yuan J and Wang Q Z. Distribution and generation of deep reservoir secondary pores, Paleogene, Dongying Sag. Journal of Mineralogy 
and Petrology. 2001. 21(1): 43-47 (in Chinese)

Yuan J, Zhang S W, Qiao J, et al. Cause of formation and dynamic mechanisms in multiple medium of dissolved pores in deep formation of Dongying Sag. Acta Sedimentologica Sinica. 2007. 25(6): 840-846 (in Chinese)

Zeng $\mathrm{J} \mathrm{H}$. Effect of fluid-rock interaction on porosity of reservoir rocks in Tertiary system, Dongying Sag. Acta Petrolei Sinica. 2001. 22(4): 39-43 (in Chinese)

Zhang Q, Zhong D K, Zhu X M, et al. Pore evolution and genesis of secondary porosity of Paleogene clastic reservoirs in Dongying Sag. Oil \& Gas Geology. 2003. 24(3): 281-284 (in Chinese)

Zhang S W, Yuan J, Sui F G, et al. Multiple diagenetic environments and evolvement model in deep formation of the $4^{\text {th }}$ Member, Shahejie Formation in the northern Dongying Sag. Chinese Journal of Geology. 2007. 43(3): 576-587 (in Chinese)

Zhang S W, Zhang L Y, Zhang S C, et al. Formation of abnormal high pressure and its application in the study of oil-bearing property of lithologic hydrocarbon reservoirs in the Dongying Sag. Chinese Science Bulletin. 2009. 54: 1570-1578

Zhang Y F, Wang G Q, Fu B L, et al. The diagenesis and the origin of anomalously high porosity zone in the deep clastic reservoir in Changling fault depression. Journal of Jilin University (Earth Science Edition). 2011. 41(2): 372-376 (in Chinese)

Zhang Y G, Xue W P, Wang G L, et al. Hydrocarbon Reservoir Formation Aggregation in the Continental Rift Basin, East China. Beijing: Petroleum Industry Press. 2006. 127-131 (in Chinese)

Zhong D K, Zhu X M and Wang H J. Characteristics and genetic mechanism of deep-buried clastic reservoirs in China. Science in China Series D: Earth Sciences. 2008. 51(Supp.II): 11-19 (in Chinese)

Zhong D K, Zhu X M, Zhang Z H, et al. Origin of secondary porosity of Paleogene sandstone in the Dongying Sag. Petroleum Exploration and Development. 2003. 30(6): 51-53 (in Chinese)

Zhou Y Q, Zhou Z Z, Chen Y, et al. Research on diagenetic environmental changes of deep reservoir in Minfeng area, Dongying Sag. Earth Science Frontiers. 2011. 18(2): 268-276 (in Chinese)

Zhu S F, Zhu X M, Wang X L, et al. Zeolite diagenesis and its control on petroleum reservoir quality of Permian in northwestern margin of Junggar Basin, China. Science in China Series D: Earth Sciences. 2012. 5: 389-396

Zhu X M, Mi L J, Zhong D K, et al. Paleogene diagenesis and its control on reservoir quality in Jiyang Depression. Journal of Palaeogeography. 2006. 8(3): 296-305 (in Chinese)

Zhu X M, Wang Y G, Zhong D K, et al. Pore types and secondary pore evolution of Paleogene reservoir in the Jiyang Sag. Acta Geologica Sinica. 2007. 81(2): 197-204 (in Chinese)

Zhu X M, Zhong D K, Zhang Q, et al. Paleogene Clastic Reservoir Characteristics and Evaluation of the Jiyang Depression. Beijing: Science Press. 2008. 160-168 (in Chinese)

Zhu X M, Zhong D K, Zhang Q, et al. Sandstone diagenesis and porosity evolution of Paleogene in Huimin Depression. Petroleum Science. 2004. 1(3): 23-29

(Edited by Hao Jie) 